\title{
Soroterapia e vacinação na espiroquetoze das galinhas
}

PELO

\author{
Dr. Henrique de Beaurepaire Aragão, \\ Assistente.
}

\section{Sorotherapie und Schutzimpfung bei der Hühnerspirochætose \\ VON}

Dr. Henrique de Beaurepaire Aragĩo,

Assistenten am Institute.

$\mathbf{I}$

\section{SOROTERAPIA.}

Contribuição para o tratamento soroterapico nas molestias produzidas por germens não cultivaveis.

Com o dezenvolvimento adquirido pela soroterapia, aumenta, cada dia, o numero de molestias contra as quais se procura obter soros especificos eficazes. Nos processos morbidos, que têm por fator etiolojico um germen cultivavel, a tecnica a empregar para o preparo dos soros não oferece grandes dificuldades ; o mesmo porém, já não acontece quando se aborda o problema da soroterapia nas molestias produzidas por germens não cultivaveis. Nestas, o unico processo que se nos oferece para imunizar o animal consiste em inoculal-o com os microbios retirados do organismo infetado, de mistura com os ele-

\section{I}

SEROTHERAPIE.

Beitrag zur Serotherapie der Krankheiten, welche durch unkultivierbare Keime erzeugt werden.

In Folge der Entwicklung der Serotherapie erfährt die Zahl der Krankheiten, gegen welche wirksame spefizifische Sera gesucht werden, eine tägliche Vermehrung. Bei den Prozessen, welche durch kultivierbare Keime verursacht werden, bietet die Technik für die Herstellung der Sera keine grossen Schwierigkeiten; dagegen ändert sich dies, wenn man das Problem der Serotherapie bei solchen Krankheiten angeht, welche durch nicht kultivierbare Keime hervorgerufen werden. Hier ist das einzige Verfahren, welches die Immunisierung des Tieres ermöglicht, die Einimpfung der Mikrobien, welche dem infizierten Organismus entstammen, zugleich mit den Zellelementen, von welchen sie sich in der Praxis nicht trennen lassen. $\mathrm{Da}_{\mathrm{a}}$ jedoch, 
mentos celulares, dos quais é impossivel, praticamente, separal-os. Como, porém, a inoculação de celulas de um animal em outro de especie diversa dá lugar a elaboração, no organismo deste, a citotoxinas especificas contra as celulas que lhe são injetadas, é de prever que o soro, preparado, como acima nos referimos, de acordo com a tecnica habitual, aprezentará, ao lado das provaveis propriedades terapeuticas, uma ação citotoxica acentuada e portanto será de emprego pouco recomendavel in vivo, onde iria cauzar lezões celulares profundas, senão mortais, no animal com elle injetado. Tem sido este o grande obice á soroterapia nas molestias produzidas por germens não cultivaveis. Diante delle têm recuado muitos pesquizadores, como THEILER (I905), KoCh, MaRchoux e Simond (I906), os quais tentando a imunização contra tais germens, tiveram ocazião de observar os dezastrosos efeitos dos soros obtidos, devido á intensa ação citotoxica deles. Ora, se o grande inconveniente dos soros preparados contra os germens não cultivaveis pela inoculação do animal com a mistura de celulas e microbios, está na formação de toxinas contra as celulas do organismo, em que eles devem ser empregados, porque não impedir a elaboração de tais citotoxinas no organismo submetido a imunização? Os conhecimentos atuais sobre a imunidade, de acordo com a escola de EHRLICH, oferecem ao problema uma solução facil, lojica e do maior rigor cientifico.

A produção de anticorpos, nos ensina a teoria de EHRLICH, está em relação com a fixação aos receptores celulares do organismo de certas substancias, toxicas ou não, que, se ligando a elles, os inutilizam e provocam a sua rejeneração em excesso, donde o desprendimento de numerozas dessas cadeias laterais do protoplasma $\&$ a sua passajem para o plasma. Nestas circumstancias', desde que se torne impossivel aquella combinação, faltará, ipso facto, a condição essencial, para que a produção de anticorpos tenha logar.

O meio eficaz e absolutamente racional, wenn man Zellen eines Tieres einem andern von verschiedener Art einverleibt, in diesem spezifische Cytotoxine gebildet werden, so ist vorauszusehen, dass ein nach der gewöhnlichen Technik hergestelltes Serum neben den zu erwartenden therapeutischen Eigenschaften auch eine ausgesprochene cytotoxische Wirkung haben werde und daher seine Anwendung in vivo wenig zu empfehlen wäre, da es beim Versuchstiere eine ausgedéhnte und möglicherweise tötliche Zellschädigung bewirken würde. Dies ist das grosse Hindernis für die Serotherapie der durch unkultivierbare Keime hervorgerufenen Krankheiten, vor welchem viele Forscher, wie THEILER (I905), KOCH, MARChOUX und SimOND (I906), zurückschrekten, da sie bei dem Versuche einer solchen Immunisation Gelegenheit hatten, die in Folge starker cytotoxischer Eigenschaften verhängnisvolle Wirkung der erhaltenen Sera zu beobachten. Wenn nun aber der grosse Uebelstand solcher Sera, welche durch Einimpfung von Zellen und unkultivierbaren Mikrobien erhalten werden, in der Bildung von spezifischen Giften für die Zellen des zu vaccinierenden Tieres beruht, warum soll man nicht die Bildung solcher Zellgifte in dem zu immunisierenden Organismus verhindern? Unsere gegenwärtigen Kenntisse über die Natur der Immunität gestatten uns, im Einklange mit der EHRLICHschen Schule eine einfache, logische und streng wissenschaftliche Lösung dieses Problemes.

Wie die EhrLICHsche Theorie lehrt, hängt die Bildung der Antikörper ab von der Fixation gewisser toxischer oder ungiftiger Substanzen auf den Zellrezeptoren des Organismus, welche sich mit denselben verbinden und sie neutralisieren, wobei sie die Bildung neuer veranlassen und zwar im Ueberschusse, so dass sich viele solche Seitenketten vom Protoplasma ablösen und ins Plasma ubergehen. Wenn aber unter derartigen Umständen diese Verbindung unmöglich wird, so fehlt, ipso facto, die notwendige Bedingung für die Produktion der Antikörper.

Das wirksame und ganz rationelle 
que se nos oferece para conseguir este rezultado, consiste em introduzir no organismo a substancia, capaz de provocar nelle a formação de anticorpos citotoxicos, levando preza ao grupo haptoforo, um receptor identico, ao da celula, a que ella normalmente se fixa.

Desta forma, satisfeita a afinidade desse grupo, cessa o motivo, para que elle se fixe ao receptor celular e, por conseguinte, dezaparece a condição essencial, para que se dê a reação de imunização. A introdução no organismo de receptores, livres ou prezos a celulas, porém levando satisfeita a sua afinidade para as celulas desse organismo, pela saturação dellas pelos seus anticorpos correspondentes, impede a reação de imunização, como cabalmente provam os trabalhos de RHens, injetando em animais misturas de toxinas e antitoxinás, os de NeIsser e Lubowski (I90I) inoculando bacilos saturados por aglutininas ou então por bacteriolizinas como fizeram Pfeifer e Friedberger (Ig02) e finalmente as interessantes pesquizas do Dungern (rgoo) e SACHs (Igor) com globulos saturados por hemolizinas.

Estas demonstrações são de extraordinario valor pela segura orientação que dão ao problema da soroterapia nas molestias produzidas por germens não cultivaveis. De fato, nestas temos a injetar no organismo do animal, em que se quer preparar o soro, os microbios produtores da molestia e, juntamente com estes, as celulas ou receptores livres, que acompanham esses microbios e que, introduzidas no organismo do animal sem prévia saturação do seu poder imunizante, irão nelle provocar a formação de citotoxinas prejudiciais ao organismo do animal, em que o soro tiver de ser empre-
Mittel für die Erreichung dieses Resultates besteht darin, dass man dem Organismus eine Substanz einverleibt, welche befähigt ist, in demselben die Bildung von Antikörpern für die Cytotoxine zu veranlassen, indem sie mit der haptophoren Gruppe verankert, einen Rezeptor führt identisch mit demjenigen der Zelle, an welche sie, normaler Weise, gebunden ist.

Wird auf diese Weise die Affinität dieser Gruppe befriedigt, so fällt die Tendenz sich am Zellrezeptor $z u$ fixieren weg und hiermit zugleich die wesentliche Bedingung einer Immunisationsreaktion. Führt man in einen Organismus freie oder an eine Zelle gebundene Rezeptoren ein, deren Affinität für die Zellen dieses Organismus jedoch bereits durch die entsprechenden Antikörper gesättigt ist, so wird eine Immunisationsreaktion unmöglich gemacht; es geht dies aufs deutlichste aus den Arbeiten von RHENs, hervor, welche Tieren Mischungen von Toxinen und Antitoxinen injizierten, sowie aus denjenigen von NeIsser und Lubowski (I90r), welche mit -Agglutininen gesättigte $\mathrm{Ba}$ zillen einführten oder denjenigen von Pfeiffer und Friedberger (I902), bei welchen die Sättigung mit Bakteriolysinen stattfand und endlich aus den interessanten Versuchen von v. DuNGern (I900) und SACHS (IgOr) mit durch Hämolysine gesättigten Blutkörperchen.

Diese Ergebnisse sind von ganz besonderem Werte, weil sie dem Probleme der Serotherapie der durch nicht kultivierbare Keime hervorgerufenen $\mathrm{K}$ rankheiten eine sichere Orientierung geben. In der Tat müssen wir bei diesen den für die Herstellung des Serums dienenden Tieren die Krankheitserreger und zugleich mit ihnen die Zellen oder freien Rezeptoren, welche die Keime begleiten, einspritzen; würden diese dem tierischen Organismus ohne vorherige Sättigung ihrer immunisierenden Eigenschaften einverleibt, so würden sie bei diesem die Bildung von Cytotoxinen herbeiführen, welche für den Organismus des Tieres, bei dem das Serum angewandt werden soll, nachteilig sein. 
gado. Como proceder a saturação desses receptores celulares?

Nenhuma dificuldade oferece a tecnica a empregar para se obter esse rezultado. Provoca-se a formação de anticorpos contra essas celulas em outro animal, inoculando-o com os mesmos elementos celulares, retirados dum animal são, e assim obtem-se naquelle, um soro carregado dos anticorpos necessarios á saturação dos receptores das celulas, quando em companhia dos microbios, tornando-se apenas necessario juntal-o, a mistura de celulas e microbios, em quantidade necessaria, para que todos os receptores celulares fiquem saturados por esses anticorpos. Uma vez conseguido isto, pode-se, sem perigo, injetar a mistura de microbios e celulas, com os receptores saturados, no organismo a inunizar contra aquelles, pois sob o ponto de vista da reação de imunização, nella provocada, tal mistura se comportará como se apenas nella existissem microbios, só contra estes se formando anticorpos.

Foi servindo-nos desta tecnica, que conseguimos alcançar os rezultados praticos dezejados e, em todos os portos, confirmativos das nossas vistas teoricas sobre a questão.

Determinado o processo a seguir, restava escolher a molestia, em condições de servir ás experiencias que iamos tentar, para demonstrar praticamente suas vantajens.

Nenhuma se aprezentava em melhores condições para as pesquizas, que iamos executar, do que a espiroquetoze das gallinhas, destruidora epizootia, muito comum entre nós, e que, com facilidade, se pode reproduzir no laboratorio. O germen desta molestia, o spirochaete gallinarum, é muito abundantemente encontrado, no sangue dos animais infetados, durante um certo periodo da molestia e, praticamente, pode ser considerado um germen não cultivavel.
Wie soll man bei der Sättigung dieser Zellenrezeptoren verfahren? Die Technik, welche zur Erreichung dieses Resultates. angewandt wird, bietet keine Schwierigkeiten.

Man veranlasst die Bildung von Antikörpern gegen diese Zellen, indem man dieselben Zellelemente einem gesunden Tiere entnimmt und sie einem anderen Tiere einverleibt; so erhält man bei diesem ein Serum, welches mit den, zugleich mit den Mikrobien eingeführten, zur Sättigung der Zellrezeptoren nötigen Antikörpern beladen ist ; man braucht es dann nur der Mischung von Zellen und Mikrobien in der nötigen Menge zuzusetzen, damit alle Zellrezeptoren durch diese Antikörper gesättigt werden. Ist dies einmal erreicht, so kann man die Mischung von Microbien und Zellen mit gesättigten Rezeptoren ohne Gefahr dem zu immunisirenden Organismus einspritzen, da eine solche Mischung in Beziehung auf die Auslösung einer Immunisationsreaktion sich so verhält, als ob in derselben nur Mikrobien existierten, gegen welche sich dann auch Antikörper bilden.

Indem ich diese Technik befolgte, gelang es mir die gewünschten praktischen Resultate zu erzielen, welche Punkt für Punkt die theoretischen Anschauungen in dieser Frage bestätigten.

Nachdem das zu befolgende Verfahren festgestellt war, blieb mir noch übrig eine Krankheit auszuwählen, welche zu den Versuchen dienen könnte, welche den praktischen Nachweis der Vorzüge dieses Verfahrens erbringen sollten. Keine bot für diese Versuche bessere Bedingungen, als die Hühnerspirochätose, eine hierzulande häufige, verheerende Epizootie, welche sich zudem auch im Laboratorium leicht uibertragen lässt. Der Erreger derselben, die Spirochaete gallinarum wird während einer bestimmten Krankheitsperiode in grosser Zahl im Blute der infizierten Tiere gefunden und kann in praktischer Hinsicht als unkultivierbarer Keim gelten. Als Serum- 
Como animais productores de soro nos servimos de cabras. Um primeiro grupo destes animais foi destinado a fornecer $o$ soro hemolitico que necessitavamos para saturar os receptores dos eritrocitos retirados do animal infetado, juntamente com os espiroquetes, e que, ao mesmo tempo que estes, deviam ser inoculados no animal a imunizar contra tais parazitos.

Um outro grupo de animais foi apenas inoculado com sangue desfibrinado de galinha infetada com espiroquetes, sem preparo previo algum (servindo assim de dupla testemunha para os inoculados com sangue do animal infetado, porém levando os receptores globulares saturados pela hemolizina especifica) comparando-se entre elles não só o poder hemolitico como o imunizante adquirido.

Finalmente, o terceiro grupo de animais foi utilizado para o preparo do soro imunizante, não hemolitico, pela inoculação, nestes animais, de sangue de galinha infetada, de mistura ao soro hemolitico, necessario á saturação de todos os receptores dos eritrocitos.

Cabem, agora, aqui algumas palavras sobre a tecnica, empregada para a obtenção dos diferentes soros, cujos detalhes mais minuciozos se encontram em outro trabalho nosso (I905), não havendo motivo, por isso, para reproduzil-os todos aqui.

Para o preparo do soro simpiesmente hemolitico, de que necessitavamos para a saturação dos receptores globulares, fizemos, nas cabras, repetidas inoculações subcutaneas de sangue desfibrinado, ocilando a quantidade de cada vez entre 20 a 60 cc. Depois de cada um desses animais ter recebido em sucessivas inoculações 80 a 100 cc. de sangue 0 seu soro aprezentava forte poder hemolitico, que se mantinha mais ou menos igual, repetindo as inoculações com 10 a 20 dias de intervalo.

O soro de cabra, já normalmente hemolitico para o sangue de galinha (na proporção de $0,24 \mathrm{cc}$. para 2 cc. de uma sus- produzenten verwandte ich Ziegen und zwar wurde die erste Gruppe dieser Tiere zur Lieferung des hämolytischen Serums bestimmt. Letzteres brauchte ich für die Sättigung der Rezeptoren der Erithrocyten, welche den infizierten Tieren zugleich mit den Spirochäten entnommen wurden, um mit diesen zusammen dem zu immunisierenden Tiere eingespritzt $z u$ werden. Eine zweite Gruppe dieser Tiere wurde nur mit defibriniertem Blute von an Spirochätose leidenden Hühnern ohne weiteren Zusatz geimpft, um auf diese Weise in doppelter Weise als Zeugen zu dienen für diejenigen, welche mit infiziertem Blute, dessen Zellrezeptoren aber durch spezifische Hämolysine gesättigt waren, vorbehandelt wurLen. Es wurde dann bei beiden Gruppen nicht nur die erworbene Immunität verglichen. Die dritte Gruppe wurde endlich bei der Herstellung des nicht hämolytischen Immunserums verwandt, indem den Tieren infiziertes Hühnerblut mit einem zur Sättigung aller Rezeptoren der Erythrocyten genügenden Zusatze von hämolytischem Serum eingespritzt wurde.

Hier sind einige Bemerkungen am Platze betreffs der Technik, welche zum Zwecke der Gewinnung der verschiedenen Sera befolgt wurde; die genaueren Einzelheiten finden sich in einer anderen Arbeit von mir (1905) und brauchen daher hier nicht wiedergegeben $z u$ werden.

Für die Herstellung des einfachen hämolytischen Serums, dessen ich zur Sättigung der Blutkörperchenrezeptoren bedurfte, machte ich den Ziegen wiederholt Einspritzungen von defibriniertem Blute, dessen Menge jeweilen zwischen 20 und $60 \mathrm{cbcm}$. schwandkte. Bei jedem Tiere, welches in wiederholten Einspritzungen 80-100 cc. erhalten hatte, zeigte das Serum hochgradige hämolytische Eigenschaften, welche sich ziemlich gleich blieben, wenn die Einspritzungen in Zwischenräume von $10 \longrightarrow 20$ Tagen wiederholt wurden.

Das Ziegenserum ist für Hühnerblut schon normalerweise hämolytisch bis zu einem Verhältnisse von $0,24 \mathrm{zu} 2 \mathrm{cbcm}$. 
pensão a $5 \%$ em agua fiziolojica ( $\mathrm{Nacl}$, $0,85 \%$ ) de globulos de galinha, adquire apóz o tratamento acima descrito um poder dissolvente, em média, 6 vezes mais intenso, o que o torna praticamente utilizavel para a saturação dos receptores globulares. O soro homolitico aprezenta, comparativamente ao normal, um poder toxico muito mais acentuado. Com uma inoculação de 2 a 3 cc. delle, por via endovenoza, se consegue matar um frango de 600 gramas em menos de 12 horas; ao passo que, com o soro normal, o mesmo rezultado só é obtido com dózes de 6 a 8 cc. Nos animais, que sucumbem á ação do soro, é muito patente a aglutinação e a dissolução das hematias; esta tanto mais vizivel, quanto mais demorada fôr a morte do animal.

Agora, vejamos os animais inoculados com espiroquetes : dividem-se estes em dois grupos ; porém, em cada um, só foi levado a cabo a imunização de um animal ; os demais, muito novos ainda e pouco rezistentes, sucumbiram ou foram abandonados durante a imunização em consequencia das fortes reações, provocadas pelas inoculações com grandes quantidades de sangue com espiroquetes.

A imunização com sangue infetado foi feita por via subcutanea, recebendo os animais de cada vez $50 \mathrm{cc}$. de sangue desfibrinado, que era obtido pela sangria de diversás galinhas doentes, no decurso do $4 .^{\circ}$ a $5^{\circ}$ dia $\mathrm{da}$-molestia, quando são muito abundantes no seu sangue os parazitos. Essas galinhas eram infetadas pela inoculação do sangue de um frango que adquirira a molestia pela picada de argas.

Tanto o animal, simplesmente inoculado com sangue infetado, sem preparo algum, como aquelle, em que os globulos eram saturados pelas hemolizinas, receberam, cada um, a mesma quartidade de sangue, $250 \mathrm{cc}$, em 5 inoculações, espaçadas por cerca de 4 mezes. Foram assim, tanto quanto possivel, colocados has mesmas condizins. einer $5 \%$ Suspension in physiologischer Lösung $(0,85 \% \mathrm{Na}$. Cl. $)$. Nach der oben beschriebenen Behandlung erwirbt es ein, im Mittel, sechsmal stärkeres Auflösungsvermögen, wodurch es für die Sättigung der Blutkörperchenrezeptoren praktisch brauchbar wird. Mit dem normalen verglichen, bietet das hämolytische Serum viel ausgesprochenere toxische Eigenschaften. Die intravenöse Einführung von $2-3 \mathrm{cbcm}$. desselben führt den Tod eines Huhnes von 600 Gramm in weniger als I 2 Stunden herbei, während zur Erreichung desselben Effectes $6-8 \mathrm{cc}$. von normalem Serum nötig sind. Bei den Tieren, welche der Serumwirkung erliegen, ist die Agglutination und Auflösung der Hämatien sehr evident, letztere um so mehr, je länger sich der Tod des Tieres verzögert.

Gehen wir jetzt zu den mit Spirochäten geimpften Tieren über, so teilen sich dieselben in zwei Grupen; doch wurde in jeder derselben nur bei einem Tiere die Immunität zu Ende geführt. Die anderen, welche noch sehr jung oder wenig widerstandfähig waren, erlagen oder wurden während der Immunisierung aufgegeben, weil die Einspritzung gröserer Mengen spirochätenhaltigen Blutes starke Reaktionen hervorrief.

Die Immunisierung mit infiziertem Blute geschah auf subkutanem Wege, indem jedes Tier auf einmal ca. $50 \mathrm{cbcm}$. defibrinierten Blutes, welches. verschiedenen Hühnern entnommen wurde und zwar am vierten bis fünften Krankheitstage, da alsdann die Spirochäten im Blute sehr zahlreich sind. Diese Hühner waren durch Finspritzung von Blut eines in Folge des Bisses von Argaszecken erkrankten Huihnchens infiziert worden.

Sowohl das Tier, dem ohne weiteren Zusatz nur infiziertes Blut eingespritzt wurde, wie dasjenige bei dem die Blutkörperchenrezeptoren durch Hämolysin gesättigt worden waren, erhielten jedes $25^{\circ}$ cbcm. in 5 Einspritzungen, welche über 4 Monate verteilt waren. So befanden sie sich, soviel wie möglich, in gleichen Verhältnissen. 
Assim, a cabra inoculada com o sangue infetado, não preparado, que nós designaremos pelas letras B. S., recebeu, de cada vez, a quantidade de sangue desfibrinado, acima mencionada, sem preparo algum.

Muito diversa foi a tecnica, empregada na cabra D. S., em que procuramos obter o soro, antiespiroquetico, porém não dotado de propriedades hemoliticas. Este animal recebeu, durante o periodo em que esteve submettido á imunização, a mesma quantidade de sangue, que o precedente. isto é, 250 cc. em 5 injeções; apenas o material, neste cazo, só era inoculado, depois de se ter completamente saturado os receptores dos globulos vermelhos, nelle existentes.

A tecnica empregada para obter a com pleta saturação dos receptores foi a seguinte: Tomavamos a quantidade de sangue, com espiroquetes, a injetar $(50 \mathrm{cc}$.) e a ella juntavamos uma doze de soro hemolitico fresco, 5 vezes superior á necessaria para dissolver completamente os globulos; pois é sabido que existe grande diferença entre a quantidade de hemolizina, necessaria para dissolver completamente um certo numero de globulos, e a suficiente para saturar completamente os receptores delles. Essa mistura de sangue infetado e soro hemolitico era colocada na estufa a $37^{\circ}$ durante 2 horas. No fim deste prazo, nós procuravamos verificar, se na mistura havia ainda hemolizinas livres, indicando portanto a completa saturação dos recpetores globulares. Para isso tomavamos uma pequena quantidade, $0,05 \mathrm{cc}$, da mistura em questão e a juntavamos a uma suspensão a $5 \%$ de globulos de galinha, em prezença de $0, I$ cc. de soro normal fresco de cabra, como fornecedor de alexna. Se os globulos eram dissolvidos apóz cerca de $1 / 2$ hora de estufa a 37 , era sinal de que, na mistura de sangue de galinha infetada com espiroquetes e soro de cabra hemolitico para galinha, todos os receptores globulares estavam saturados e ainda havia um excesso de hemolizinas livres. Quando,
So erhielt die mit dem hämolytischen Blutte, ohne Zusatz, behandelten Ziege, die ich mit den Buchstaben B. S. bezeichne, jedesmal das oben angegebene Quantum defibrinierten Blutes ohne Vorbereitung

Sehr verschieden war dagegen die befolgte Technik bei der Ziege D. S., bei welcher ich ein Antispirochäten Serum ohne hämolytische Eigenschaften zu erhalten suchte. Dieses Tier erhielt in der Zeit, während welcher es der Immunisation unterworfen wurde, dieselbe Blutmenge, wie das vorhergehende, nämlich $250 \mathrm{cbm}$., in 5 Injektionen; nur wurde das Material, in diesem Falle erst eingespritzt, nachdem die in demselben enthaltenen Rezeptoren der roten Blutkörperchen vollkommen gesättigt waren.

Um die vollständige Sättigung der Rezeptoren herbeizuführen, befolgte ich folgendes Verfahren: Ich nahm das zur Einspritzung bestimmte Quantum spirochätenhaltigen Blutes $(5 \circ \mathrm{Cbcm}$.) und setzte demselben das hämolytische Serum und zwar in einer fünfmal grösseren Menge, als zur vollständigen Lösung der roten Blutkörperchen nötig war. Man weiss ja, dass zwischen der Hämolysinmenge, welche zur vollständigen Auflösung einer bestimmten $Z$ ahl von Blutkörperchen nötig ist, und derjenigen, welche zur vollständigen Sättigung der Rezeptoren genügt, ein grosser Unterschied besteht. Diese Mischung von infiziertem Blute und hämolytischem Serum wurde 2 Stunden in einem Brutschranke bei 37 Grad gehalten. Nach Ablauf dieser Zeit versuchte ich festzustellen, ob in der Mischung noch freie Hämolysine existierten, was eine vollständige Sättigung der Blutkörperchenrezeptoren anzeigen musste. $\mathrm{Zu}$ diesem $\mathrm{Zwecke}$ nahm ich von der fraglichen Mischung eine kleine Menge, $0,05 \mathrm{cc}$, und mischte sie mit einer $5 \%$ Suspension von Hühnerblutkörperchen, in Gegenwart von $0, \mathrm{I} \mathrm{Cbcm}$. frischen Ziegenblutes, welches das Alexin lieferte. Wurden die Blutkörperchen binnen einer halben Stunde im Brutschranke aufgelöst, so zeigte dies, dass in der Mischung von Spirochäten, Hühnerblut und für das 
porém, a mistura se mostrava incapaz de dissolver novos globulos (indicando a auzencia de amboceptores hemoliticos livres), juntava-se nova quantidade de soro hemolitico e faziam-se as mesmas verificações, quanto á prezença de hemolizinas, depois de novo periodo de I hora na estufa. Algumas vezes, foi precizo recorrer á quantidade de soro hemolitico, Io vezes superior á necessaria, para dissolver completamente os globulos.

Somente, quando, na mistura de globulos, espiroquetes e soro hemolitico, nós verificamos a prezença do excesso de hemolizinas livres, é, que a injetavamos no animal.

Apezar de introduzirmos, por esse modo, de cada vez, no organismo do animal, submettido á imunização, uma certa quantidade de hemolizinas livres, a imunização passiva, que adquiria o animal por conta da inoculação dessas hemolizinas, era bastante insignificante e della não restavam vestijios por ocazião das sangrias, feitas 12 a 15 dias depois a injeção da mistura de sangue com espiroquetes e soro hemolitico; sendo portanto esse prazo suficiente para fazer dezaparecer do organismo as hemolizinas livres, estranhas, nelle injetadas.

Esta tecnica de supersaturação dos receptores globulares (que julgamos a que deve ser empregada em todas as imunizações contra germens não cultivaveis) nos conduziu ao mais completo rezultado. O soro da cabra D. S., apóz o prazo necessario para a imunização, não aprezentava, sob o ponto de vista hemolitico, propriedades toxicas, superiores ás que tem normalmente o soro de cabra para os globulos de galinha, e, no ponto de vista terapeutico, nenhuma diferença mostrava em comparação ao da cabra B. S., sómente inoculada com o sangue infetado não preparado.

Assim, anteriormente á imunização, o soro da cabra D. S. dissolvida 2 cc. de uma suspensão, a $5 \%$ de globulos de galinha, na dóze de 0,24 cc. ; esse poder hemolitico letztere lytisch wirkendem Ziegenblute alle Rezeptoren gesättigt waren und noch ein Ueberschuss von freiem Hämolysin existierte. Zeigte sich dagegen die Mischung unfähig, in Folge Abwesenheit freier hämolytischer Ambozeptoren, neue Blutkörperchen aufzulösen, so fügte ich ein neues Quantum hämolytischen Serums hinzu und machte, nach weiterem einstündigem Aufenthalte im Brutschrank, eine neue Bestimmung. Einige Male war es nötig, eine Dosis hämolytischen Serums anzuwenden, welche zehnmal mehr betrug, als das zur vollständigen Lösung der roten' Blutkörperchen nötige. Erst, wenn ich in der Mischung von Blutkörperchen, Spirochäten und hämolytischem Serum die Gegenwart eines Ueberschusses von freiem Hämolysin festgestellt hatte, wurde diesselbe dem Tiere eingespritzt.

Obgleich ich auf diese Weise jedesmal eine gewisse Menge von freien Hämolysinen in den Organismus des zu immunisierenden Tieres einführte, so war doch die passive Immunisation, welche das Tier durch dieselbe erfuhr, ziemlich gering und es zeigte sich von derselben bei den 12-I5 Tage später gemachten Aderlässen keine Spur mehr, so dass diese Frist genügt, um die injizierten Hämolysine aus dem Organismus verschwinden $\mathrm{zu}$ lassen.

Diese Technik der Uebersättigung der Globularrezeptoren, von der ich glaube, dass sie bei allen Immunisationen gegen nicht kultivierbare Keime gebraucht werden sollte, führte zu einem vollen Erfolge. Nach der zur Immunisierung nötigen Frist, zeigte das Serum der Ziege $\mathbf{D}$. $\mathbf{S}$. in Beziehung auf Hämolyse nicht ausgesprochenere Giftwirkungen, als sie das Ziegenserum normalerweise für Hühnerblutkörperchen zeigt und andererseits in therapeutischer Hinsicht keinen Unterschied beim Vergleiche mit demjenigen der Ziege B. S., welche nur mit infiziertem Blute ohne Zusatz behandelt worden war.

So löste vor der Immunisierung das Serum der Ziege D. S. 2 Cc. einer $5 \%$ igen Suspension von Hühnerblutkörperchen in der Dose von 0,24 Cc.; 
não aprezentou alteração alguma, quer durante, quer apóz o tratamento. Empregado in vivo por via intravenoza, o soro desse animal só se mostrou toxico, para um frango de cerca de 600 gramas, na dóze dt 6 a 8 cc., comportando-se assim, como o soro normal de cabra, ao passo, que o soro da cabra B. S., sómente inoculada com o sangue infetado mas não preparado já se mostrava toxico para um animal do mesmo pezo, na dóze de 2 a 3 cc. Injetando-se o soro da cabra D. S., na dóze de Io cc., por via subcutanea, a um frango de 600 gra mas, não se notava nenhuma alteração sen sivel na quota globular, ao passo, que os animais inoculados com o soro da cabra B. S., perdiam, apóz uma identica injeção, em 24 horas, na media, 2 milhões de globulos vermelhos por milimetro cubico, devido ao forte poder toxico dess esoro.

São particularmente interessantes, a este respeito, e muito demonstrativos tambem, os rezultados das inoculações intravenozas, feitas com as duas especies de soro, empregando-os no tratamento da infeção, 6 e 18 horas apóz a injeção do germen, e, uzando respectivamente para combatel-a, as dózes de 3 e 5 cc. de soro das cabras B. S. e D. S.

Nestas experiencias, ao passo que os animais tratados com o soro da cabra D. S., não só suportavam perfeitamente as inoculações, como não aprezentavam manifestação alguma da molestia, os tratados, nas mesmas condições, com o soro da cabra B. S. sucumbiram todos ás consequencias da inoculação do soro desse animal, em prazo que ocilou entre 15 minutos e 5 horas (Serie de experiencias expostas nos quadros M. e N.)

Agora, comparemos o valor dos dois soros sob o ponto de vista terapeutico.

Para isso empregamos os dois soros nas mesmas dózes, quer, preventivamente, 24 horas antes da infeção, quer ao mesmo tempo que ella, quer, depois della, até 24 horas apóz a infeção. Estas expe- dieses hämolytische Vermögen zeigte weder während, noch nach der Behandlung irgend welche Veränderung. In vivo und introvenös angewandt, zeigte sich dieses Serum für ein Huhn von ca. 600 Gramm erst in einer Dose von 6-8 Cc. toxisch und verhielt sich demgemäss wie normales Ziegenserum, während das Serum der Ziege B. S., die nur mit infiziertem Blute ohne Zusatz geimpft war, sich schon in der Dosis von 2-3 Cc. für ein Tier desselben Gewichtes toxisch zeigte. Injizierte ich ro Cc. Serum von der Ziege D. S. unter die Haut eines Huhnes von 600 Gramm, so beobachtete man keine deutliche Veränderung in der Zahl der roten Blutkörperchen, während die Tiere, denen Serum der Ziege B. S. eingespritzt wurde, in Folge der hohen Toxicität dieses Serums, schon nach einer Injektion im Mittel 2 Millionen roter Blutkörperchen per Kubikmillimeter einbüssten.

Sehr interessant und demonstrativ sind in dieser Hinsicht auch die Resultate der intravenösen Injektionen, beider Serumarten, welche 6-I8 Stunden nach Einspritzung der Keime gemacht wurden; dabei kamen für die Behandlung Dosen von 3 und $5 \mathrm{Ccm}$. des Serums der Ziegen B. S. und D. S. zur Anwendung.

Während bei diesen Versuchen die mit Serum von Ziege D. S. behandelten Tiere nicht nur die Einspritzungen sehr gut ertrugen, sondern auch überhaupt keine Krankheitserscheinungen darboten, erlagen die in derselben Weise mit Serum von Ziege B. S. behandelten alle den Folgen der Serumeinspritzung und zwar innerhalb einer Frist, die zwischen $\mathbf{I}_{5}$ Minuten und 5 Stunden schwankte. (S. die in Tabellen $\mathrm{M}$ und $\mathrm{N}$ aufgeführten Versuchsreihen):

Gehen wir jetzt zu dem Vergleiche beider Sera in ihrer therapeutischen Wirkung uiber. Hier wandte ich die beiden Sera in derselben Dosis an und zwar teils präventiv 24 Stunden vor der Infektion, teils gleichzeitig mit derselben, teils-bis zu 24 Stunden-nach derselben. Diese in zahlreichen Serien und jeweilen an einer grösseren $\mathrm{Zahl}$ von Tieren vorgenommenen 
riencias feitas em numerozas series e, cada vez, em grande numero de animais, constam dos quadros $\mathrm{A}$ a $\mathrm{L}$ e demonstram que, sob o ponto de vista, quer curativo, quer preventivo, o valor dos dois soros se mostrou identico, não influindo, portanto, o processo de saturação dos ieceptores globulares sobre o rezultado da imunização. Nos animais, tratados com dózes elevadas de soro da cabra B. S., foi sempre muito notavel a anemia, proveniente do seu poder toxico para os globulos vermelhos.

Tambem identica se mostrou a ação dos dois soros in vitro, ao cabo de meia hora os espiroquetes eram por elles imobilizados sem, comtudo, aprezentarem sinal algum de bacteriolize. Qualquer dos soros, empregados em prazo superior a 24 horas apóz a infeção (de $3 \circ$ horas em diante), se mostrou sempre ineficaz, mesmo utilizado em dózes elevadas, quer por via subcutanea, quer por intravenoza, (até $40 \mathrm{cc}$. da cabra D. S.). Como está provado por trabalho de Levaditi (I904), que a partir de 24 horas os espiroquetes, inoculados no animal, começam a aparecer no sangue periterico, parece ser lojico admittir, em avista dos rezultados obtidos até esse prazo, que o soro só atua, emquanto os espiroquetes se acham nas grandes visceras. Tendo sido as series de animais, tratados apóz 24 horas de infeção, sempre negativas, deixamos de as mencionar em detalhe no prezente trabalho.

Do exposto até aqui, nos parece ficar absolutamente provada a possibilidade da obtenção de soros, a todo o ponto de vista eficazes, no tratamento das molestias, produzidas por germens não cultivaveis, e, ao mesmo tempo, completamente destituidos de propriedades hemoliticos, decorrentes do processo da imunização. Diante dos rezultados obtidos nada se opõe a que á mesma tecnica, que empregamos, seja dado - mais largo uzo na soroterapia das molestias, produzidas por germens não cultivaveis, ampliando-a ás numerozas outras infeções do mesmo genero, contra os quais,
Versuche sind aus den Tabellen A bis $\mathrm{L}$ ersichtlich und beweisen den übereinstimmenden Wert beider Sera, sowohl für die Vorbeugung als für die Bekämpfung der Krankheit, so dass der Prozess der Sättigung der Rezeptoren der Blutkörperchen das Resultat der Immunisation nicht beeinflusst. Bei den mit Serum der Ziege B. S. in hohen Dosen behandelten Tieren war die Anämie als Folge seiner Giftigkeit für die roten Blutkörperchen immer sehr auffallend.

Die Wirkung der beiden Sera zeigte sich auch in vitro als gleichwertig; nach einer halben Stunde waren die Spirochäten durch ihre Wirkung unbeweglich geworden, ohne jedoch anzeichen von Bakteriolyse zu bieten. Mehr wie 24 Stunden nach der Infektion (von 30 Stunden an) zeigte sich die Anwendung beider Sera immer wirkungslos, sei es, dass sie subkutan, sei es, dass sie intravenös in hohen Dosen (bei Ziege D. S. bis zu $40 \mathrm{Ccm}$.) angewandt wurden. Da aus der Arbeit von Levaditı (I904) feststeht, dass eingeimpfte Spirochäten schon nach 24 Stunden im peripherischen Blute der Tiere aufzutreten beginnen, so scheint es, mit Rücksicht auf die bis zu dieser Frist erzielten Erfolge, logisch anzunehmen, dass das Serum nur wirkt, so lange sich die Spirochäten in den Zentralorganen aufhalten. $\mathrm{Da}$ die Resultate der Behandlung nach mehr wie 24 stündiger Frist seit der Infektion immer negativ waren, unterlasse ich ihre nähere Anführung in dieser Arbeit.

Durch das eben auseinandergesetzte scheint mir unzweifelhaft erwiesen, dass man Sera herstellen kann, welche bei der Behandlung von durch unkultivierbare Keime hervorgerufenen Krankheiten in jeder Hinsicht wirksam und zugleich frei von solchen hämolytischen Wirkungen sind, wie sie durch den Immunisationsprozess hervorgerufen werden. Mit Hinsicht auf diese Resultate liegt kein Grund vor, warum nicht dieselbe Technik in ausgedehnter Weise bei der Serotherapie anderer durch unkultivirbare Keime hervorgerufenen Infektionem benützt werden 
até agora, a soroterapia tem estado impotente, devido aos perigos decorrentes do processo de imunização a empregar.

Por outro lado, o nosso trabalho deixa patente o valor da soroterapia na espiroquetoze das galinhas e a possibilidade de, por meio della, não só se poder segura mente prevenir a molestia, como cural-a, até ao periodo de 24 horas apóz a infeção, o que, sob o ponto de vista pratico, tem uma grande utilidade, permitindo que, aos primeiros cazos de infeção em um galinheiro, se ponha a salvo os animais, que ainda se acharem em periodo de incubação do mal.

\section{II}

\section{VACINAÇÃO NA ESPIROQUETOZE DAS GALINHAS.}

A obtenção de uma vacina contra a espiroquetoze das galinhas tem grande alcance sob o ponto de vista pratico, pois oferece um meio, de se evitar as destruidoras epizootias, tão comuns nos galinheiros, em que existem argas infetados e onde tão dificil é a completa destruição, desses acarianos. Essas epizootias se reproduzem a cada nova introdução nesses galinheiros, de aves, vindas de zonas, onde não existe a infeção, e que portanto não gozam de imunidade, adquirida a custa de um ataque anterior não mortal da molestia. Acontecendo que a espiroquetoze das galinhas confere aos animais, que della escapam, notavel imunidade, muito fundadas eram as nossas esperanças de que, introduzindo no organismo de animais não imunes o virus sob uma forma atenuada ou morta, pudessemos obter uma vacina eficaz contra ella.

Naturalmente, aqui, como na soroterapia, se impunha o emprego do sangue de animais infetados, como material para o preparo da vacina.

Morrendo o germen ao cabo de poucos dias no sangue desfibrinado, a primeira idea que vem é a de se empregar esse sangue contendo os germens mortos para a sollte, wo sich die Wissenschaft wegen der durch die Immunisation veranlassten Gefahren bisher ohnmächtig gezeigt hat.

Auf der anderen Seite erweist meine Arbeit den Wert der Serotherapie bei der Hühnerspirochätose und die Möglichkeit durch jene nicht nur der Krankheit mit Sicherheit vorzubeugen, sondern sie auch bis 24 Stunden nach der Infektion zur Heilung zu bringen, was praktisch von grossem Werte ist, da es so möglich wird, beim ersten Auftreten der Infektion in einem Hühnerstalle alle Tiere zu retten, die sich noch im Inkubationsstadium der Krankheit befinden.

\section{VACCINATION BEI DER HÜHNER- SPIROCHATOSE.}

Die Herstellung einer Vaccine, gegen die Hühnerspirochätose hat einen grossen praktischen Wert, da sie uns ein Mittel zur Verhütung verheerender Epizootien bietet, wie sie so häufig in Hühnerhöfen sind. wo infizierte Argas vorkommen, deren vollständige Ausrottung sehr schwierig ist. Diese Seuchen wiederholen sich jedes Mal, wenn in solche Hühnerhöfe Tiere gebracht werden, welche aus infektionsfreien Zonen stammen und deshalb nicht die Immunität besitzen, wie sie durch einen früher überstandenen Anfall der Krankheit verliehen wird. $\mathrm{Da}$ die Hühnerspirochätose den Tieren, welche sie überstanden haben, eine ausgesprochene Immunität verleiht, so hatte ich sehr begründete Hoffnungen, eine wirksame Vaccine gegen dieselbe zu erzielen, wenn ich das Virus in abgeschwächter oder toter Form in den Organismus nicht immuner Tiere einführte.

Wie bei der Serumtherapie ergab sich auch hier die Anwendung des Blutes infizierter Tiere von selbst als Material für die Herstellung der Vaccine.

Da der Keim im defibrinierten Blute nach wenigen Tagen abstirbt, si liegt der Gedanke nahe, solches Blut mit den darin enthaltenen toten Keimen bei der Impfung 
vacinação. Ocorre porém, aqui uma grande dificuldade que é a de se obter, em grandes quantidades, sangue desfibrinado, completamente asetico, nos animais infetados.

Em prezença desta dificuldade, rezolvemos recorrer á esterilização do sangue, colhido, com a possivel asepsia, nos animais infetados. Depois de algumas tentativas com diferentes ajentes fizicos e quimicos: calor, cloroformio, toluol, formol, chegamos á concluzão, de que o formol nos oferecia as maiores vantajens, permitindonos obter uma vacina com as condições dezejadas e cuja tecnica de preparo passamos a expôr.

Com o sangue de um animal infetado por argas, inoculam-se diversas galinhas (pelo menos ro) e no $5 .^{\circ}$ dia da infeção, quando o exame de sangue revela a prezença de numerozos espiroquetes, procede-se á retirada delle. Para isso o pescoço dos animais infetados é previamente depenado, com todo o cuidado, lavado com uma solução de lizol a $5 \%$, depois, com agua fiziolojica e finalmente enxuto com algodão asetico. Uma vez feita a asepsia da rejião, cortam-se por meio de um bisturi; esterilizado e bem afiado, os vazos da rejioã lateral do pescoço, junto á cabeça, tendo o cuidado de não atinjìr os condutos alimentar e respiratorio, evitando, assim, que o sangue se contamine fortemente.

Secionados os vazos do pescoço, o sangue, que delles corre, é recebido em um balâo de vidro esterilizado, de capacidade de 300 gramas, em cujo interior foram colocadas pequenas esferas de porcelana, destinadas a desfibrinação, e a cujo gargalo se adapta um pequeno funil de vidro, tambem esterilizado, para maior facilidade da recep̧̧ão do sangue no interior do balão.

Logo que o sangue cessa de correr abundantemente da ferida e começa a gotejar, interrompe-se a sangria, tapandose o gargalo do balão com uma mecha de algodão testeril e se ajita rapidamente o sangue até se obter completa desfibrinação delle. Uma vez desfibrinado, o sangue é passado para um balão esterilizado, no qual se vão reunindo as quantidades que $\mathrm{zu}$ verwenden. Jedoch begegnet man hier der grossen Schwierigkeit der Gewinnung grösserer Mengen defibrinierten Blutes bei vollständiger Wahrung der Asepsis.

Diese Schwierigkeit berücksichtigend, beschloss ich von der Sterilisation des möglichst aseptisch den infizierten Tieren entnommenen Blutes Gebrauch zu machen. Nach einingen Versuchen der Anwendung physikalischer und chemischer Mittel : Hitze, Chloroform, Toluol und Formol ergab sich das letzteres die grössten Vorzüge, indem es mir gestattete, unter den gewünschten Bedingungen eine Vaccine zu erhalten, deren Herstellung hier erörtert werden soll.

Mit dem Blutte eines durch Argas infizierten Tieres werden wenigstens Io Hühner geimpft und am fünften Tage der Infektion, wenn die Untersuchung das Vorhandensein zahlreicher Spirochäten im Blute erweist, wird zur Entnahme desselben geschritten. Hierfür wird der Hals der infizierten Tiere sorgfältig von Federn befreit, mit einer fünfprozentigen Lysollösung und dann mit physiologischer Lösumg gewaschen und endlich mit Bäuschchen aseptischer Watte getrocknet. Nachdem die Asepsis der Region beendet ist, werden mittelst sterilen und sehr scharfen Bistouris, die Gefässe der seitlichen Halsregion nahe am Kopfe durchschnitten, wobei man Luft- und Speiseröhre sorgfältig schont und so eine stärkere Verunreinigung vermeidet.

Nach Durchschneidung der Halsgefässe wird das aus ihnen fliessende Blut in sterilisierten Ballons von 300 Gramm Gehalt aufgefangen; dieselben wurden zuvor zum Zwecke der Defibrinierung mit Porzellanschrot beschickt und in ihrem Halse befindet sich, zwecks leichteren Auffangens des Blutes, ein ebenfalls steriler Trichter.

Sobald das Blut aufhört, reichlich aus der Wunde zu fliessen und nur tröpfelt, wird der Aderlas unterbrochen, der Ballon mit einem sterilisierten Wattebausch verpfropft und das Blut lebhaft geschüttelt, bis es vollständig defibriniert ist ; dann wird es 
fornece cada animal, de modo que se obtem assim uma igual distribuição de germens na quantidade total de sangue. Terminada a sangria, o sangue obtido é distribuido, por meio de uma pipeta esterilizada, em vidros de boca larga, da capacidade de 125 gramas na proporção de 50 cc. para cada vidro; estes são então arrolhados com um pouco de algodão, embebido em formol, tendo-se porem o cuidado de evitar que este antisetico não escorra para dentro dos vidros, só devendo os seus vapores exercer a ação esterilizante sobre o sangue. Estes vidros permanecem assim fechados por 24 horas, sendo então o sangue delles reunido, de novo, em um balão èsterilizado, simplesmente arrolhado com um pouco de algodão asetico ; aqui permanece por 8 dias, tendo-se o cuidado de ajitar frequentemente o conteudo para impedir a formação de grumos. Ao cabo desse prazo o sangue é semeado em meios para cultura de aerobios e anaerobios e, uma vez verificado que nelle nenhum germen vivo existe, distribuido em tubos de capacidade de I5 cc.; estes contem I5 dózes da vacina, pois a quantidade, que empregamos na imunização, é de I cc. por animal, o que corresponde perfeitamente ás necessidades da pratica. $\mathrm{O}$ aspeto da vacina depois de promta é o de um liquido espesso de cor parda escura ou avermelhada. Os espiroquetes apresentam-se nella com a sua morphologia quasi intacta e geralmente aglomerados.

A vacina, assim preparada, submetida a variadas provas em numerozos animais, a diferentes provas em numerozos animais, tem se mostrado de poder imunizante seguro e duradouro, conservando a sua atividade normal por prazo superior a um ano apóz o seu preparo. As diferentes experiencias, á que tem sido submetida a vacina neste instituto e das quais rezulta a sua utilidade sob todos os pontos de vista, vem abaixo mencionadas nas series de experiencias expostas nos quadros $\mathrm{O}$ a $\mathrm{V}$.

$E^{\prime}$ inutil, insistir sobre as vantajens, que na pratica o seu emprego aprezenta, oferecendo um meio seguro de pôr, nos in einem anderen sterilisierten Ballon mit den von den anderen Tieren gewonnenen Mengen vermischt, so dass in der Gesammtblutmenge eine gleichmässige Verteilung der Keime erreicht wird. Nach vollendeter Entnahme wird das gewonnene Blut mittelst steriler Pipette auf weithalsige Gläser von I 25 Gramm Inhalt verteilt, so dass jedes 50 Gramm enthält ; diese werden dann mit in Formol getränkter Watte verschlossen, wobei man sorgfältig vermeidet, dass dasselbe in die Gläser läuft, da nur die Dämpfe ihre sterilisierende Wirkung auf das Blut ausüben sollen. Diese Gläser bleiben während 24 Stunden geschlossen, worauf das Blut aus denselben wieder in einem sterilisierten Ballon vereinigt und letzterer mit einem Wattepfropf verschlossen wird. Hier bleibt es 8 Tagen während welcher für öfteres Umschütteln zu sorgen ist, um die Bildung von Klümpchen zu verhüten. Am Ende dieser Zeit wird das Blut auf für gewöhnliche und anärobische Keime passende Nährböden ausgesät und nach festgestellter Abwesenheit solcher Keime auf Tuben von I 5 Cc. Gehalt verteilt. Letztere enthalten I Vaccinedose, da die zur Immunisierung eines Tieres verwandte Menge I Cc. beträgt, was den Anforderungen der Praxis vollständig entspricht. Die fertige Vaccine erscheint als eine dicke, dunkelbraune oder rötlich Flüssigkeit. Die Spirochäten in derselben zeigen eine fast völlig unveränderte Form und sind gewöhnlich in Haufen vereinigt.

Die so hergestellte Vaccine wurde verschiedenen Proben bei zahlreichen Tieren unterworfen und zeigte ein zuverlässiges und anhaltendes Immunisierungsvermögen, indem sie ihre normale Wirksamkeit noch nach mehr als Jahresfrist bewahrt. Die verschiedenen Proben, welchen sie im Institute unterworfen wird und aus denen ihre Brauchbarkeit in jeder Hinsicht hervorgeht, finden sich unten in Tabellen $\mathrm{O}$ bis $\mathrm{V}$ aufgeführt.

Es ist unnötig, auf die Vorteile einzugehen, welche der Gebrauch der Vaccine in der Praxis gewährt, indem sie ein sicheres 
galinheiros infetados, as aves ao abrigo da espiroquetoze, quando vacinadas antes de nelles serem introduzidas.

Ultimamente, temos nos ocupado com o preparo de uma vacina contra a espiroquetoze, substituindo ao formol a glicerina, adicionada em partes iguais ao sangue. A vacina, assim obtida e que empregamos na doze de 2 cc. para cada animal, goza igualmente de propriedades imunizantes notaveis e semelhantes á da vacina preparada pelo formol; as nossas experiencias, porém, sendo de data recente, não nos fornecem ainda criterio seguro sobre a duração e a conservação do seu poder imunizante. A vacina, preparada pelo formol, como pela glicerina, nós a temos até agora empregada por via subcutanea ; julgamos, que nos galinheiros infetados, uma só vacinação, basta porquanto a picada dos argas infetados só tornará a imunidade mais solida, sendo obsolutamente desnecesaria qualquer nova inoculação da vacina. Quanto aos galinheiros não infetados (em que a vacinação fôr feita com o fim de garantir os animais contra as probabilidades da importação da infeção), nelles a revacinação não deverá ser feita antes de um ano, pois as experiencias demonstram que a vacina confere imunidade suficiente até esse prazo. A inoculação da vacina nenhum perigo oferece para os animais, ainda mesmo quando muito novos ou enfraquecidos por uma cauza qualquer.

Aqui encerramos a expozição dos nossos rezultados sobre a vacinação contra $o$ espiroquetoze, cujo emprego nos parece de todo o ponto recomendavel, como um dos meios mais praticos para se obter a profilaxia da dezimadora epizootia, tão comum entre nós. A mesma tecnica que usamos se recommenda, egualmente ao nosso ver, para o preparo de vacinas para as demais espiroquetozes como a Tick fever, a febre recurrente etc.

Manguinhos, Outubro de I9ro.
Mittel bietet, um die Vögel in einem infizierten Hüherhofe vor der Spirochätose zu schützen, wenn man sie vor dem Einbringen in denselben impft.

Neuerdings habe ich mich mit der Herstellung einer Vaccine befasst, in welcher das Formol durch dem Blute zu gleichen Teilen beibefügtes Glyzerin ersetzt wird. Die so erhaltene Vaccine, welche ich in der Dosis von $2 \mathrm{Cbcm}$. per Tier anwandte, besitzt ebenfalls hervorragende immunisierende Eigenschaften, wie diejenige, welche mit Formol hergestellt wurde; doch sind meine Versuche neueren Datums und gestatten mir noch kein sicheres Urteil uiber die Dauer und Erhaltung des Immunisierungsvermögens. Die Vaccine, sowohl die mit Formol, als auch die mit Glyzerin hergestellte, habe ich bis jetzt immer subkutan angewandt; ich halte auch eine einmalige Impfung in infizierten Hühnerhöfen für genügend, da die Bisse der infizierten Argaszecken, die Immunität nur verstärken, so dass jede weitere Vaccination unnötig ist. Bei nicht infizierten Hühnerhöfen, wo die Imfung nur zum $Z$ wecke des Schutzes der Tiere gegen eine importierte Infektion geschieht, braucht die Revaccination nicht vor einem Jahre stattzufinden, da die Versuche zeigen, dass die Vaccination bis zu diesem Termin eine genügende Immunität verleiht. Die Einimpfung der Vaccine bildet selbst für sehr junge oder aus irgend einem Grunde geschwächte Tiere keine Gefahr.

Hier schliesse ich die Erörterung der Resultate, welche ich bei der Impfung gegen Spirochätose erhielt ; die Anwendung des Verfahrens scheint mir in jeder Hinsicht empfehlenswert, als eines der brauchbarsten Mittel für die Prophylaxe der hier zu lande so häufigen und verheerenden Epizootie. Die von mir gebrauchte Technik empfiehlt sich, meines Erachtens, auch zur Herstellung von Vaczine gegen die anderen Spirochätosen, wie Tick fever, Recurrens u. s. w.

Manguinhos, Oktober 19 ro. 


\section{VERIFICAÇÕES FEITAS COM OS SOROS ANTIESPIROQOETICOS}

Serie $A$

Ensaio do soro da cabra BS

(Antiespiroquetico bemolitico)

Animais tratados preventivamente 24 horas antes da infeção

\begin{tabular}{|c|c|c|c|}
\hline ANIMAI. & $\begin{array}{l}\text { QUANT. DE GERMENS } \\
\text { (INJEÇAO SUB-CUTANEA) }\end{array}$ & $\begin{array}{c}\text { QUANT. DE SORO } \\
\text { (INJEÇÃO SUB-GUTANEA) }\end{array}$ & REZULTADO \\
\hline $\begin{array}{l}\text { Frango } \mathrm{n} .1 \\
\text { Testemunha } \\
680 \text { grms. } \\
\text { Frango } \mathrm{n} .2 \\
520 \text { grms. } \\
\text { Frango } \mathrm{n} .3 \\
650 \text { grms. } \\
\text { Frango n. } 4 \\
570 \text { grms. } \\
\text { Frango n. } 5 \\
570 \text { grms. } \\
\text { Frango } \mathrm{n} .6 \\
570 \text { grms. } \\
\text { Frango } \mathrm{n} .7 \\
515 \text { grms. } \\
\text { Frango } \mathrm{n} .8 \\
610 \text { grms. } \\
\text { Frango n. } 9 \\
640 \text { grms. } \\
\text { Frango n. } 10 \\
630 \text { grms. }\end{array}$ & $\begin{array}{l}0,1 \text { cc de sangue com espi- } \\
\text { roquetes. }\end{array}$ & $\begin{array}{l}0,5 \text { cc soro normal de } \\
\text { cabra. } \\
0,1 \text { cc soro especifico. } \\
0,1 \text { cc soro especifico. } \\
0,2 \text { cc soro especifico. } \\
0,2 \text { cc. soro especifico. } \\
0,5 \text { cc soro especifico. } \\
1 \text { cc soro especifico. }\end{array}$ & $\begin{array}{l}\text { Todos estes animaes ad. } \\
\text { quiriram espiroquetoze- }\end{array}$ \\
\hline
\end{tabular}

PERSOCHE MIT DEN ZWEI HERGESTELLTEN ARTEN YON SEROM GEGEN SPIROCHAETOSIS

Serie $A$

Versuche mit Serum von Ziege BS

(Spirochătentötendes und hămolytisches Serum)

24 Stunden vor der Infektion behandelte Tiere

\begin{tabular}{|c|c|c|c|}
\hline TIER & $\begin{array}{c}\text { DOSIS DES VIRUS } \\
\text { (SUBKUTANE INJECTION) }\end{array}$ & $\begin{array}{l}\text { DOSIS DES SERUMS } \\
\text { (SUBKUTANE INJECTION) }\end{array}$ & RESULTAT \\
\hline $\begin{aligned} & \text { Huhn n. } \text { n } \\
& \text { Zeuge } \\
& 680 \text { grms. } \\
& \text { Huhn } \text { n. } 2 \\
& 520 \text { grms. } \\
& \text { Huhn } \text { n. } 3 \\
& 650 \text { grms. } \\
& \text { Huhn } \text { n. } 4 \\
& 570 \text { grms. } \\
& \text { Huhn } \text { n. } 5 \\
& 570 \text { grms. } \\
& \text { Huhn n. } 6 \\
& 570 \text { grms. } \\
& \text { Huhn } \text { n. } 7 \\
& 515 \text { grms. } \\
& \text { Huhu n. } 8 \\
& 610 \text { grms. } \\
& \text { Huhn n. } 9 \\
& 640 \text { grms. } \\
& \text { Huhn n. } 10 \\
& 630 \text { grms. }\end{aligned}$ & $\begin{array}{l}0,1 \text { cc. Blut mit spiro. } \\
\text { chäten. }\end{array}$ & $\begin{array}{l}0,5 \text { cc normales Ziegen. } \\
\text { serum. } \\
0,1 \text { cc spezifisches Serum. } \\
0,1 \text { cc speziftches Serum. } \\
0,2 \text { cc spezifisches Serum. } \\
0,2 \text { cc spezifisches Serum. } \\
0,5 \text { cc spezifisches Serum. } \\
1 \text { cc spezifisches Serum. }\end{array}$ & $\left\{\begin{array}{l}\text { Keines der Tiere zeigt } \\
\text { Erscheindngen von Spi- } \\
\text { rochătose. }\end{array}\right.$ \\
\hline
\end{tabular}


Serie $B$

Ensaio do soro da cabra BS

(Antiespiroquetico hemolitico)

Animais tratados pelo soro e ao mesmo tempo infetados

\begin{tabular}{|c|c|c|c|}
\hline ANIMAL & $\begin{array}{l}\text { QUANT. DE GERMENS } \\
\text { (INJEÇAO SUB-CUTANEA) }\end{array}$ & $\begin{array}{c}\text { QUANT. DE SORO } \\
\text { (INJEÇÃO SUB CUTANEA) }\end{array}$ & REZULTADO \\
\hline $\begin{array}{l}\text { Frango } \mathrm{n} .1 \\
\text { Testemunha } \\
690 \text { grms. } \\
\text { Frango } \mathrm{n} .2 \\
640 \text { grms. } \\
\text { Frango } \mathrm{n} .3 \\
600 \text { grms. } \\
\text { Frango } \mathrm{n} .4 \\
580 \text { grms. } \\
\text { Fran5o } \mathrm{n} .5 \\
610 \text { grms. } \\
\text { Frango } \mathrm{n} .6 \\
575 \text { grms. } \\
\text { Frango } \mathrm{n} .7 \\
610 \text { grms. } \\
\text { Frango } \mathrm{n} .8 \\
600 \text { grms. } \\
\text { Frango } \mathrm{n} .9 \\
680 \text { grms. } \\
\text { Frango n. } 10 \\
700 \text { grms. }\end{array}$ & $\begin{array}{l}0,1 \text { ce de sangue com espi- } \\
\text { roquetes. }\end{array}$ & $\begin{array}{l}1, \text { cc soro normal de cabra. } \\
0,2 \text { cc soro especifico. } \\
0,5 \text { cc soro especifico. } \\
0,5 \text { cc soro especifico. } \\
1 \text { cc soro especifico. }\end{array}$ & $\begin{array}{l}\text { Todos estes animais ad- } \\
\text { quiriram espiroquetoze. } \\
\text { Nenhum destes animals } \\
\text { manifestaçoes da infe. } \\
\text { çăo espiroquetica. }\end{array}$ \\
\hline
\end{tabular}

Serie $B$

Versuche mit Serum von Ziege B S

(Spirochätentötendes und hämolytisches Serum)

Gleichzeitig infizierte und mit Serum behandelte Tiere

\begin{tabular}{|c|c|c|c|}
\hline TIER & $\begin{array}{c}\text { DOSIS DES VIRUS } \\
\text { (SUBKUTANE INJEKTION) }\end{array}$ & $\begin{array}{c}\text { DOSIS DES SERUMS } \\
\text { (SUBKUTANE INJEKTION) }\end{array}$ & RESULTAT \\
\hline $\begin{aligned} & \text { Huhn } \text { n. } 1 \\
& \text { Zeuge } \\
& 690 \text { grms. } \\
& \text { Huhn } \text { n. } 2 \\
& 640 \text { grms. } \\
& \text { Huhn } \text { n. } 3 \\
& 600 \text { grms. } \\
& \text { Huhn } \text { n. } 4 \\
& 580 \text { grms. } \\
& \text { Huhn } \text { n. } 5 \\
&611) \text { grms.! } \\
& \text { Huhn } \text { n. } 6 \\
& 575 \text { grms. } \\
& \text { Huhn } \text { n. } 7 \\
& 610 \text { grms. } \\
& \text { Huhn } \text { n. } 8 \\
& 600 \text { grms. } \\
& \text { Huhn } \text { n. } 9 \\
& 680 \text { grms. } \\
& \text { Huhn } \text { n. } 10 \\
& 700 \text { grms. }\end{aligned}$ & $\begin{array}{l}0,1 \text { cc Blut mit Spiro- } \\
\text { chäten. }\end{array}$ & $\begin{array}{l}1 \text { cc normales Ziegenserum. } \\
0,2 \text { cc spezifisehes Serum. } \\
0,5 \text { cc spezifisches Serum. } \\
0,5 \text { cc spezifisches Serum. } \\
1 \text { cc spezifisches Serum. }\end{array}$ & $\begin{array}{l}\text { Alle diese Tiere erk rank- } \\
\text { ten an Spirochătose. } \\
\text { Keines der Tiere zeigt } \\
\text { Erscheinungen von Spi- } \\
\text { rochătose. }\end{array}$ \\
\hline
\end{tabular}


Serie $C$.

Ensaios do soro da cabra BS

(Antiespiroquetico hemolitico)

Animais tratados 6 horas apóz a infeção

\begin{tabular}{|c|c|c|c|}
\hline A NIMAL & $\begin{array}{c}\text { QUAN'T. DE GERMENS } \\
\text { (INJEÇAO SUR-CUTANEA) }\end{array}$ & $\begin{array}{c}\text { QUANT. DE SORO } \\
\text { (INJEÇĀO SUB-CUTANEA) }\end{array}$ & REZULTADO \\
\hline $\begin{array}{l}\text { Frango n. } 1 \\
\text { Testemunha } \\
720 \text { grms. } \\
\text { Frango n. } 2 \\
750 \text { grms } \\
\text { Frango n. } 3 \\
715 \text { grms. } \\
\text { Frango n. } 4 \\
690 \text { grms. } \\
\text { Frango n. } 5 \\
645 \text { grms. } \\
\text { Frango n. } 6 \\
600 \text { grms. } \\
\text { Frango } \mathrm{n} .7 \\
700 \text { grms. } \\
\text { Frango n. } 8 \\
675 \text { grms. }\end{array}$ & $\begin{array}{l}0,1 \mathrm{cc} \text { de sangue com espi- } \\
\text { roquetes. }\end{array}$ & $\begin{array}{l}3 \text { cc soro normal de cabra. } \\
1 \text { cc soro especifico. } \\
2 \text { cc soro especifico. } \\
3 \text { ce soro especifio. }\end{array}$ & $\begin{array}{l}\text { Todos estes animais ad. } \\
\text { quiriram espiroquetoze. } \\
\text { Nenhum destes animais } \\
\text { apresentou manifestaçoes } \\
\text { da infeção espiroquetica. }\end{array}$ \\
\hline
\end{tabular}

Serie $C . \quad$ Versuche mit Serum von Ziege BS

(Spirochătentötendes und hämolytisches Serum)

6 Stunden nach der Infektion behandelte Tiere

\begin{tabular}{|c|c|c|c|}
\hline TIER & $\begin{array}{c}\text { DOSIS DES VIRUS } \\
\text { (SUBKUTANE INJEKTION) }\end{array}$ & $\begin{array}{c}\text { DOSIS DES SERUMS } \\
\text { (SUBKUTANE INJEKTION) }\end{array}$ & RESULTAT \\
\hline $\begin{array}{r}\text { Huhn n. } 1 \\
\text { Zeuge. } \\
720 \text { grms. } \\
\text { Huhn } \text { n. } 2 \\
720 \text { grms. } \\
\text { Huhn n. } 3 \\
715 \text { grms. } \\
\text { Huhn } \text { n. } 4 \\
690 \text { grms. } \\
\text { Huhn n. } 5 \\
645 \text { grms. } \\
\text { Huhn n. } 6 \\
600 \text { grms. } \\
\text { Huhn n. } 7 \\
700 \text { grms. } \\
\text { Huhn n. } 8 \\
675 \text { grms. }\end{array}$ & $\begin{array}{l}0,1 \text { cc Blut mit Spiro- } \\
\text { chäten. }\end{array}$ & $\begin{array}{l}3 \text { cc normales Ziegenserum. } \\
1 \text { cc spezifisches Serum. } \\
2 \text { cc spezifisches Serum. } \\
3 \text { cc spezifisches Serum. }\end{array}$ & $\begin{array}{l}\text { Alle diese Tiere erkrank- } \\
\text { ten an Spirochätose. } \\
\text { Keines der Tiere zeigt } \\
\text { Erscheinungen von Spi- } \\
\text { rochätose. }\end{array}$ \\
\hline
\end{tabular}


Serie $D$

Ensaios do soro da cabra BS

(Antiespiroquetico hemolitico)

Animais tratados 18 horas apóz a infeção

\begin{tabular}{|c|c|c|c|}
\hline ANIMAL & $\begin{array}{l}\text { QUANT. DE GERMFNS } \\
\text { (INJEÇAO SUB-CUTANEA) }\end{array}$ & $\begin{array}{c}\text { QUANT. DE SORO } \\
\text { (INJEÇÄO SUB-CUTANEA) }\end{array}$ & REZULTADO \\
\hline $\begin{array}{l}\text { Frango n. } 1 \\
\text { Testemunha } \\
820 \text { grms. } \\
\text { Frango n. } 2 \\
800 \text { grms. } \\
\text { Frango n } 3 \\
810 \text { grms. } \\
\text { Frango n. } 4 \\
765 \text { grms. } \\
\text { Frango n. } 5 \\
780 \text { grms. } \\
\text { Frango n. } 6 \\
735 \text { grms. } \\
\text { Frango n. } 7 \\
655 \text { grms. } \\
\text { Frango n. } 8 \\
735 \text { grms. }\end{array}$ & $\left\{\begin{array}{l}0,1 \text { cc de saugue com espi- } \\
\text { roquetes: }\end{array}\right.$ & $\begin{array}{l}5 \text { cc soro normal de cabra. } \\
3 \text { cc soro especifico. } \\
4 \text { cc soro especifico. } \\
5 \text { cc soro especifico }\end{array}$ & $\begin{array}{l}\text { Todos estes animaes ad- } \\
\text { quiriram espiroquetoze. } \\
\\
\text { Nenhum destes animaes } \\
\text { apresentou manifesta- } \\
\text { çôes da infecção espi- } \\
\text { roquetica. }\end{array}$ \\
\hline
\end{tabular}

Serie $D$

Versuche mit Serum von Ziege BS

(Spirochätentötendes und bämolytisches Serum)

18 Stunden nach der Infektion behandelte Tiere

\begin{tabular}{|c|c|c|c|}
\hline TIER & $\begin{array}{l}\text { DOSIS DES VIRUS } \\
\text { (SURKUTANE INJEKTION) }\end{array}$ & $\begin{array}{l}\text { DOSIS DES SERUMS } \\
\text { (SUBKUTANE INJEKTION) }\end{array}$ & RESULTAT \\
\hline $\begin{array}{r}\text { Huhn n. } 1 \\
\text { Zeuge } \\
820 \text { grms. } \\
\text { Huhn } \text { n. } 2 \\
800 \text { grms. } \\
\text { Hubn n. } 3 \\
810 \text { grms. } \\
\text { Huhn n. } 4 \\
765 \text { grms. } \\
\text { Huhn n. } 5 \\
780 \text { grms. } \\
\text { Huhn n. } 6 \\
735 \text { grms. } \\
\text { Huhn n. } 7 \\
655 \text { grms. } \\
\text { Huhn n. } 8 \\
735 \text { grms. }\end{array}$ & $\begin{array}{l}0,1 \text { cc. Blut mit Spiro- } \\
\text { chäten. }\end{array}$ & $\begin{array}{l}5 \text { cc normales Ziegen- } \\
\text { serum. } \\
3 \text { cc spezifisches Serum. } \\
4 \text { cc spezifisches Serum. } \\
5 \text { cc spezifisches Serum. }\end{array}$ & $\begin{array}{l}\text { Alle diese Tiere erkrank- } \\
\text { ten an Spirochätose. }\end{array}$ \\
\hline
\end{tabular}


Ensaio do soro de cabra BS

(Antiespiroquetico hemolitico)

Animais tratados 24 horas apóz a infeção

\begin{tabular}{|c|c|c|c|}
\hline ANIMAI. & $\begin{array}{c}\text { QUAN'T. DE GERMENS } \\
\text { (INJEÇAO SUB-CUTANEA) }\end{array}$ & $\begin{array}{c}\text { QUANT. DE SORO } \\
\text { (INJECÇAO SUB-CUTANEA) }\end{array}$ & REZULTADO \\
\hline $\begin{array}{c}\text { Frango n. } 1 \\
\text { Testeminha } \\
690 \text { grms. } \\
\text { Frango n. } 2 \\
700 \text { grms. } \\
\text { Frango n. } 3 \\
680 \text { grms. } \\
\text { Frango n, } 4 \\
645 \text { grms. } \\
\text { Frango n. } 5 \\
645 \text { grms. } \\
\text { Frango n. } 6 \\
700 \text { grms. } \\
\text { Frango n. } 7 \\
570 \text { grms, } \\
\text { Frango n. } 8 \\
590 \text { grms. }\end{array}$ & $\begin{array}{l}0,1 \text { cc de sangue com es- } \\
\text { piroquetes. }\end{array}$ & $\begin{array}{l}10 \mathrm{cc} \text { soro normal de cabra. } \\
5 \mathrm{cc} \text { soro especifico. } \\
8 \mathrm{cc} \text { soro especifico. } \\
10 \mathrm{cc} \text { soro especifico. }\end{array}$ & $\begin{array}{l}\text { Todos estes animais ad- } \\
\text { quiriram espiroquetoze. } \\
\\
\text { Nenhum destes animais } \\
\text { apresentou manifesta- } \\
\text { çōes de infecção espi- } \\
\text { roquetica. }\end{array}$ \\
\hline
\end{tabular}

Serie $E$

Versuche mit serum von Ziege BS

(Spirochätentötendes und hämolytisches Serum

24 Stunden nach der Infektion behandelte Tiere

\begin{tabular}{|c|c|c|c|}
\hline TIER & $\begin{array}{l}\text { DOSIS DES VIRUS } \\
\text { (SUBKUTANE IUJEKTION) }\end{array}$ & $\begin{array}{l}\text { DOSIS DES SERUMS } \\
\text { (SUBKUTANE INJEKTION) }\end{array}$ & RESULTAT \\
\hline $\begin{array}{c}\text { Huhn n. } 1 \\
\text { Zeuge } \\
690 \text { grms. } \\
\text { Huhn n. } 2 \\
700 \text { grms. } \\
\text { Huhn n. } 3 \\
680 \text { grms. } \\
\text { Huhn n. } 4 \\
645 \text { grms. } \\
\text { Huhn n. } 5 \\
645 \text { grms. } \\
\text { Huhn n. } 6 \\
700 \text { grms. } \\
\text { Huhn n. } 7 \\
570 \text { grms. } \\
\text { Huhn n. } 8 \\
590 \text { grms. }\end{array}$ & $\begin{array}{l}0,1 \text { cc Blut mit Spiro- } \\
\text { chăren. }\end{array}$ & $\begin{array}{l}10 \text { cc normales Ziegen- } \\
\text { serum. } \\
5 \text { cc speziflsches serum. } \\
8 \text { cc spezifisches serum. } \\
10 \text { cc spezifisches Serum. }\end{array}$ & $\begin{array}{l}\text { Alle diese Tiere erkrank- } \\
\text { ten an Spirochätose. } \\
\text { Keines der Tiere zeigt } \\
\text { Esscheinung von Spi- } \\
\text { rochătose. }\end{array}$ \\
\hline
\end{tabular}


Ensaio do soro da cabra BS

(Antiespirilico hemoquetico)

Animais tratados 24 horas apóz a infeção

\begin{tabular}{|c|c|c|c|}
\hline ANIMAL & $\begin{array}{l}\text { QUANT. DE CERMENS } \\
\text { (INJEÇÃO SUB CUTANEA) }\end{array}$ & $\begin{array}{c}\text { QUANT. DE SORO } \\
\text { (INJEÇĀAO SUB CUTANEA) }\end{array}$ & REZULTADO \\
\hline $\begin{array}{l}\text { Frango n. } 1 \\
\text { Testemunha } \\
680 \text { grms. } \\
\text { Frango n. } 2 \\
520 \text { grms. } \\
\text { Frango n. } 3 \\
650 \text { grms. } \\
\text { Frango n. } 4 \\
590 \text { grms. } \\
\text { Frango n. } 5 \\
570 \text { grms. } \\
\text { Frango n. } 6 \\
515 \text { grms. } \\
\text { Frango n. } 7 \\
510 \text { grms. } \\
\text { Frango n. } 8 \\
530 \text { grms. } \\
\text { Frango n. } 9 \\
640 \text { grms. }\end{array}$ & $\begin{array}{l}0,1 \text { cc de sangue com espi- } \\
\text { roquetes. }\end{array}$ & $\begin{array}{l}10 \mathrm{cc} \text { soro normal de cahra. } \\
5 \mathrm{cc} \text { soro especifico } \\
8 \mathrm{cc} \text { suro espeeifico. } \\
9 \mathrm{cc} \text { soro especifico }\end{array}$ & $\begin{array}{l}\text { Nenhum destes animaes } \\
\text { aprezentou manifesta- } \\
\text { çōes da infeção espiro- } \\
\text { quetica. }\end{array}$ \\
\hline
\end{tabular}

Serie $F$

Versuche mit Serum von Ziege BS

(Spirochätentöntedes und hämolytisches Serum)

24 Studen nach der Infektion behandelt Tiere

\begin{tabular}{|c|c|c|c|}
\hline TIER & $\begin{array}{c}\text { DOSIS DES VIRUS } \\
\text { (SUBKUTANE INJEKTION) }\end{array}$ & $\begin{array}{l}\text { DOSIS DES SERUMS } \\
\text { (SUBKUTANE INJEKTION) }\end{array}$ & REZULTAT \\
\hline $\begin{array}{r}\text { Huhn n. } 1 . \\
\text { Zeuge } \\
680 \text { grms. } \\
\text { Huan n. } 2 \\
520 \text { grms. } \\
\text { Huhn n. } 3 \\
650 \text { grms. } \\
\text { Huth n. } 4 \\
590 \text { grms. } \\
\text { Huhn n. } 5 \\
570 \text { grms. } \\
\text { Huhn n. } 6 \\
515 \text { grms. } \\
\text { Huhn n. } 7 \\
510 \text { grms. } \\
\text { Huhn n. } 8 \\
530 \text { grms. } \\
\text { Huhn n. } 9 \\
640 \text { grms. }\end{array}$ & $\begin{array}{l}0,1 \text { cc Blut mit Spiro- } \\
\text { chätose. }\end{array}$ & $\begin{array}{l}10 \mathrm{cc} \text { normales Ziegenserum } \\
5 \mathrm{cc} \text { spezifisches Serum. } \\
8 \mathrm{cc} \text {. spezofisches Serum } \\
9 \mathrm{cc} \text { spezifisches Serum. }\end{array}$ & $\begin{array}{l}\text { Keines der Tiere zeigt } \\
\text { Erscheimungen von Spi- } \\
\text { rochätose. }\end{array}$ \\
\hline
\end{tabular}


Serie $G$

Ensaio do soro, da cabra DS

(Antiespiroquetico não hemolitico)

Animais tratados preventivamente 24 horas antes da infeção

\begin{tabular}{|c|c|c|c|}
\hline ANIMAL & $\begin{array}{c}\text { QUANT. DE GERMENS } \\
\text { (INJEÇÃO SUB-CUT } \% \text { NEA) }\end{array}$ & $\begin{array}{c}\text { QUANT. DE SORO } \\
\text { (INJEÇÃO SUB-CUTANEA) }\end{array}$ & REZULTADO \\
\hline $\begin{array}{l}\text { Frango n. } 1 \\
\text { Testemunha } \\
700 \text { grms. } \\
\text { Frango n. } 2 \\
575 \text { grms. } \\
\text { Frango n. } 3 \\
715 \text { grms. } \\
\text { Frango n. } 4 \\
690 \text { grms. } \\
\text { Frango n. } 5 \\
640 \text { grms. } \\
\text { Frango n. } 6 \\
615 \text { grms. } \\
\text { Frango n. } 7 \\
610 \text { grms. } \\
\text { Frango n. } 8 \\
700 \text { grms. } \\
\text { Frango n. } 9 \\
625 \text { grms. } \\
\text { Frango n. } 10 \\
645 \text { grms. }\end{array}$ & $\begin{array}{l}0,1 \text { cc de sangue com espi- } \\
\text { roquetes. }\end{array}$ & $\begin{array}{l}0,5 \text { cc soro normal de cabra. } \\
0,1 \text { cc soro especifico. } \\
0,1 \text { cc soro especifico. } \\
02 \text { cc soro especifico. } \\
0,2 \text { cc soro especifico. } \\
0,5 \text { cc soro especifico. } \\
1 \text { cc soro especifico. }\end{array}$ & $\begin{array}{l}\text { Nenhum destes animaes } \\
\text { anresentou manifesta- } \\
\text { çoes da infecçáo isp̣i- } \\
\text { roquetica. }\end{array}$ \\
\hline
\end{tabular}

Serie G

Versuche mit Serum von Ziege DS

(Nicht hämolytisches Serum gegen Spirochätose)

24 Stunden vor der Infektion behandelte Tiere

\begin{tabular}{|c|c|c|c|}
\hline TIER & $\begin{array}{c}\text { DOSIS DES VIRUS } \\
\text { (SUBKUTANE INJEKTION) }\end{array}$ & $\begin{array}{c}\text { DOSIS DES SERUMS } \\
\text { (SUBKUTANE INJEKTION) }\end{array}$ & RESULTAT \\
\hline $\begin{array}{r}\text { Huhn n. } 1 \\
\text { Zeuge } \\
700 \text { grms. } \\
\text { Huhn n. } 2 \\
575 \text { grms. } \\
\text { Huhn } \text { n. } 3 \\
715 \text { grms. } \\
\text { Huhn } \text { n. } 4 \\
690 \text { grms. } \\
\text { Huhn n. } 5 \\
640 \text { grms. } \\
\text { Huhn n } 6 \\
615 \text { grms. } \\
\text { Huhn n. } 7 \\
610 \text { grms. } \\
\text { Huhn n. } 8 \\
700 \text { grms. } \\
\text { Huhn n. } 9 \\
625 \text { grms. } \\
\text { Huhn n. } 10 \\
645 \text { grms. }\end{array}$ & $\begin{array}{l}0,1 \text { cc Blut mit Spiro- } \\
\text { chätose. }\end{array}$ & $\begin{array}{l}0,5 \text { normales Ziegenserum. } \\
0,1 \text { cc spezifisches Serum. } \\
0,1 \text { cc spezifisches Serum. } \\
0,2 \text { cc spezifisches Serum. } \\
0,2 \text { cc spezifisches Sernm. }\end{array}$ & $\begin{array}{l}\text { Keines der Tiere zeigt } \\
\text { Erscheinungen von Spi- } \\
\text { rochätose. }\end{array}$ \\
\hline
\end{tabular}


Serie $\boldsymbol{H}$

Ensaio do soro da cabra DS

(Antiespiroquetico não hemolitico)

Animais tratados pelo soro e ao mesmo tempo infetados

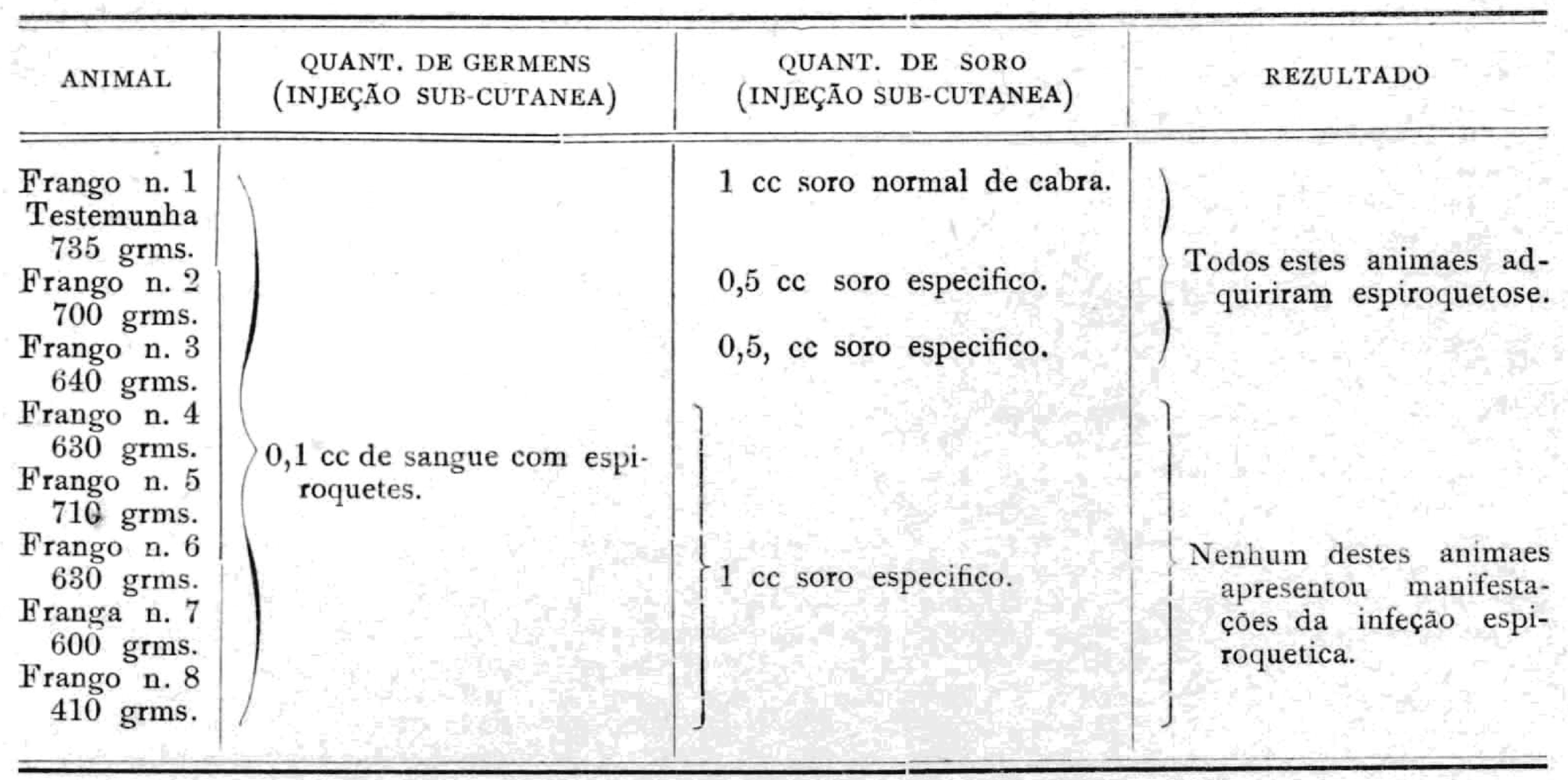

Serie $H$ Versuche mit Serum von Ziege DS

(Nicht hämolytisches Serum gegen Spirochätose) Gleichzeitig infizierte und mit Serum behandelte Tiere

\begin{tabular}{|c|c|c|c|}
\hline TIER & $\begin{array}{c}\text { DOSIS DE VIRUS } \\
\text { (sUBKUTANE } \\
\text { INJEKTION) }\end{array}$ & $\begin{array}{c}\text { DOSIS DE SERUMS } \\
\text { (SUBKUTANE INJEKTION) }\end{array}$ & RESULTAT \\
\hline $\begin{array}{r}\text { Huhn n. } 1 \\
\text { Zeuge } \\
735 \text { grms. } \\
\text { Huhn n. } 2 \\
700 \text { grms. } \\
\text { Huhn n. } 3 \\
640 \text { grms. } \\
\text { Huhn n. } 4 \\
630 \text { grms. } \\
\text { Huhn n. } 5 \\
710 \text { grms. } \\
\text { Huhn n. } 6 \\
630 \text { grms. } \\
\text { Huhn n. } 7 \\
600 \text { grms. } \\
\text { Huhn n. } 8 \\
4 \mathrm{I} 0 \text { grms. }\end{array}$ & $\begin{array}{l}0,1 \text { cc Blut mit Spiro- } \\
\text { chäten. }\end{array}$ & $\begin{array}{l}1 \mathrm{cc} \text { normales Ziegenserum. } \\
0,5 \mathrm{cc} \text { spezifisches Serum. } \\
0,5 \mathrm{cc} \text { spezifisches Serum. } \\
1 \text { cc espezifisches Serum. }\end{array}$ & $\begin{array}{l}\text { Alle diese Tiere erkrank- } \\
\text { ten an Spirochätose. } \\
\text { Keines der Tiere zeigt } \\
\text { Erscheinung von Spi- } \\
\text { rochätose. }\end{array}$ \\
\hline
\end{tabular}




\section{Ensaio do soro da cabra DS}

(Antiespiroquetico não hemolitico)

Animais tratados 6 horas apóz a infeção

\begin{tabular}{|c|c|c|c|}
\hline ANIMAL & $\begin{array}{c}\text { QUANT. DE GERMENS } \\
\text { (INJEÇÃO SUB-CUTANEA) }\end{array}$ & $\begin{array}{c}\text { QUANT. DE SORO } \\
\text { (INJEÇÃO SUB-CUTANEA) }\end{array}$ & REZULTADO \\
\hline $\begin{array}{c}\text { Frango n. } 1 \\
\text { Testemunha } \\
720 \text { grms. } \\
\text { Frango n. } 2 \\
655 \text { grms. } \\
\text { Frango n. } 3 \\
680 \text { grms. } \\
\text { Frango n. } 4 \\
645 \text { grms. } \\
\text { Frango n. } 5 \\
7 \mathrm{I0} \text { grms. } \\
\text { Frango n. } 6 \\
625 \text { grms. } \\
\text { Frango n. } 7 \\
600 \text { grms. } \\
\text { Frango n. } 8 \\
590 \text { grms. }\end{array}$ & $\begin{array}{l}0,1 \text { cc de sangue com spi- } \\
\text { roquetes. }\end{array}$ & $\begin{array}{l}3 \text { cc soro normal de cabra. } \\
1 \text { cc soro especifico. } \\
2 \text { cc soro especifico. }\end{array}$ & $\begin{array}{l}\text { Todos estes animaes adqui- } \\
\text { riram espiroquetoze. }\end{array}$ \\
\hline
\end{tabular}

Serie I

Versuche mit Serum von Ziege DS

(Nicht hämolytisches Serum gegen Spirochätose)

6 Stunden nach der Infektion behandelte Tiere

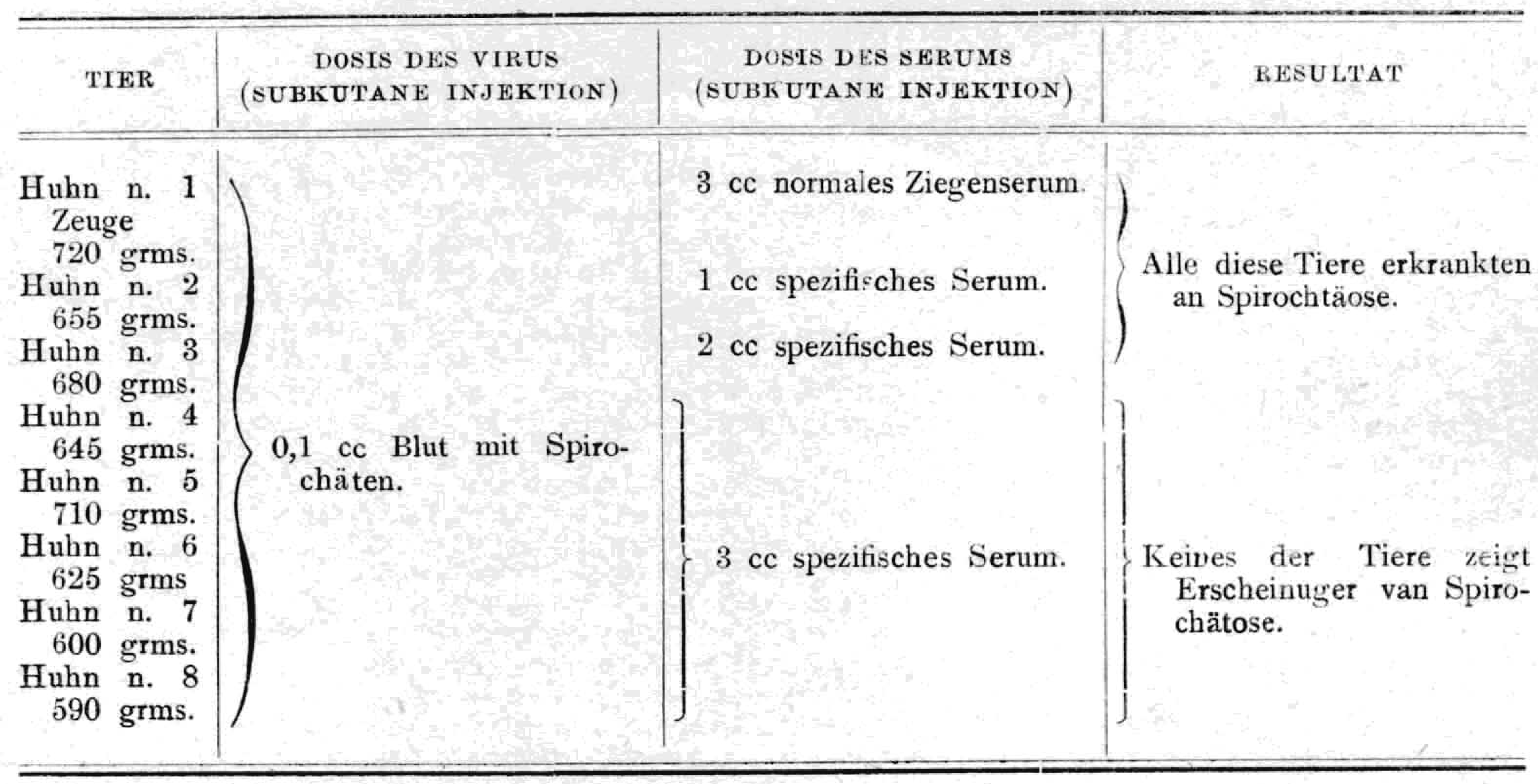




\section{Ensaio do soro da cabra DS}

(Antiespiroquetico não hemolitico)

\section{Animais tratados 18 horas apóz a infeção}

\begin{tabular}{|c|c|c|c|}
\hline ANIMAL & $\begin{array}{l}\text { QUANT. DE GERMENS } \\
\text { (INJEÇÃO SUB-CUTANEA) }\end{array}$ & $\begin{array}{l}\text { QUANT. DO SORO } \\
\text { (INJEÇÃ̃O SUB-CUTANEA) }\end{array}$ & REZULTADO \\
\hline $\begin{array}{r}\text { Frango n. } 1 \\
\text { Testemunha } \\
720 \text { grams. } \\
\text { Frango n. } 2 \\
680 \text { grams. } \\
\text { Frango n. } 3 \\
500 \text { grams. } \\
\text { Frango n. } 4 \\
650 \text { grams. } \\
\text { Frango n. } 5 \\
600 \text { grams. } \\
\text { Frango n. } 6 \\
630 \text { grams. } \\
\text { Frango n. } 7 \\
680 \text { grams. } \\
\text { Frango n. } 8 \\
610 \text { grams. }\end{array}$ & $\begin{array}{l}0,1 \text { cc de sangue com espi- } \\
\text { roquetes. }\end{array}$ & $\begin{array}{l}5 \mathrm{cc} \text { soro normal de cabra. } \\
3 \mathrm{cc} \text { soro especifico. } \\
4 \mathrm{cc} \text { soro especifico. }\end{array}$ & $\begin{array}{l}\text { Nenhum destes animaes } \\
\text { apresentou manifesta- } \\
\text { çoes da infeção espi- } \\
\text { roquetica.. }\end{array}$ \\
\hline
\end{tabular}

Serie $J$

\section{Versuche mit Serum von Ziege DS}

(Nicht hämolytisches Serum gegen Spirochätose)

18 Studen nach der Infektion behandelte Tiere

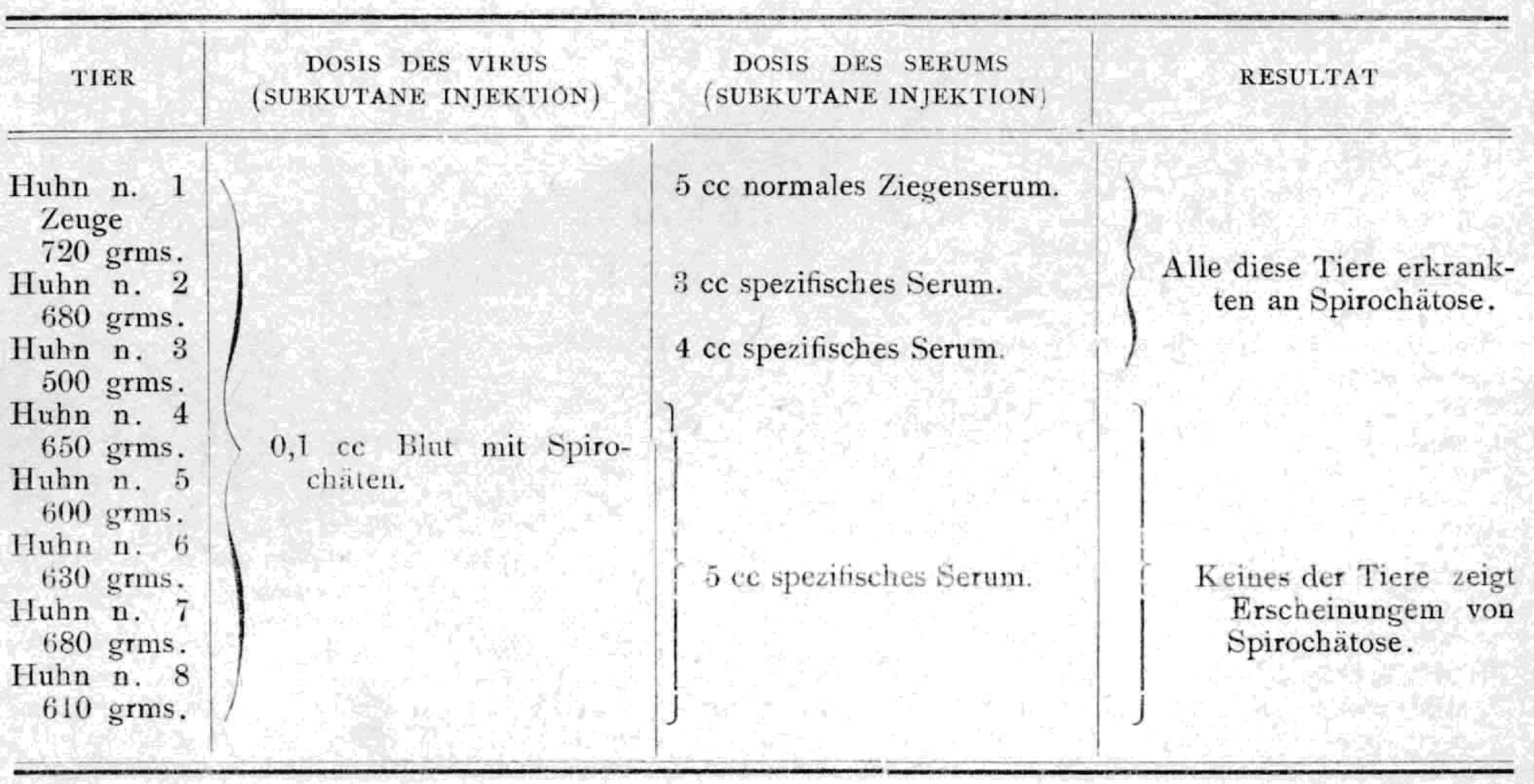


Serie $K$

Ensaio do soro da cabra DS

(Antiespiroquetico não hemolitico)

Animais tratados 24 horas apóz a infeção

\begin{tabular}{|c|c|c|c|}
\hline ANIMAL & $\begin{array}{c}\text { QUANT. DE GERMENS } \\
\text { (INJEÇÃO SUB-CUTANEA) }\end{array}$ & $\begin{array}{c}\text { QUANL. DE SORO } \\
\text { (INJEÇÃO SUB-CUTANEA) }\end{array}$ & REZULTADO \\
\hline $\begin{array}{l}\text { Frango n. } 1 \\
\text { Testemunha } \\
690 \text { grms. } \\
\text { Frango n. } 2 \\
680 \text { grms. } \\
\text { Frango n. } 3 \\
635 \text { grms. } \\
\text { Frango n. } 4 \\
525 \text { grms. } \\
\text { Frango n. } 5 \\
600 \text { grms. } \\
\text { Frango n. } 6 \\
640 \text { grms. } \\
\text { Frango n. } 7 \\
500 \text { grms. } \\
\text { Frango n. } 8 \\
670 \text { grms. } \\
\text { Frango n. } 9 \\
470 \text { grms. }\end{array}$ & $\begin{array}{l}0,1 \text { ccde sangue com espi- } \\
\text { roquetes. }\end{array}$ & $\begin{array}{l}10 \text { cc soro normal de cabra. } \\
5 \text { cc soro especifico. } \\
8 \text { cc soro especifico. } \\
9 \text { cc soro especifico. } \\
10 \mathrm{cc} \text { soro especifico. }\end{array}$ & $\begin{array}{l}\text { Todos estes animaes ad- } \\
\text { quiriram espiroquetoze. }\end{array}$ \\
\hline
\end{tabular}

Serie $K \quad$ Versuche mit Serum von Ziege DS

(Nicht hämolytisches Serum gegen Spirochätose)

24 Studen nach der Infektion behandelte Tiere

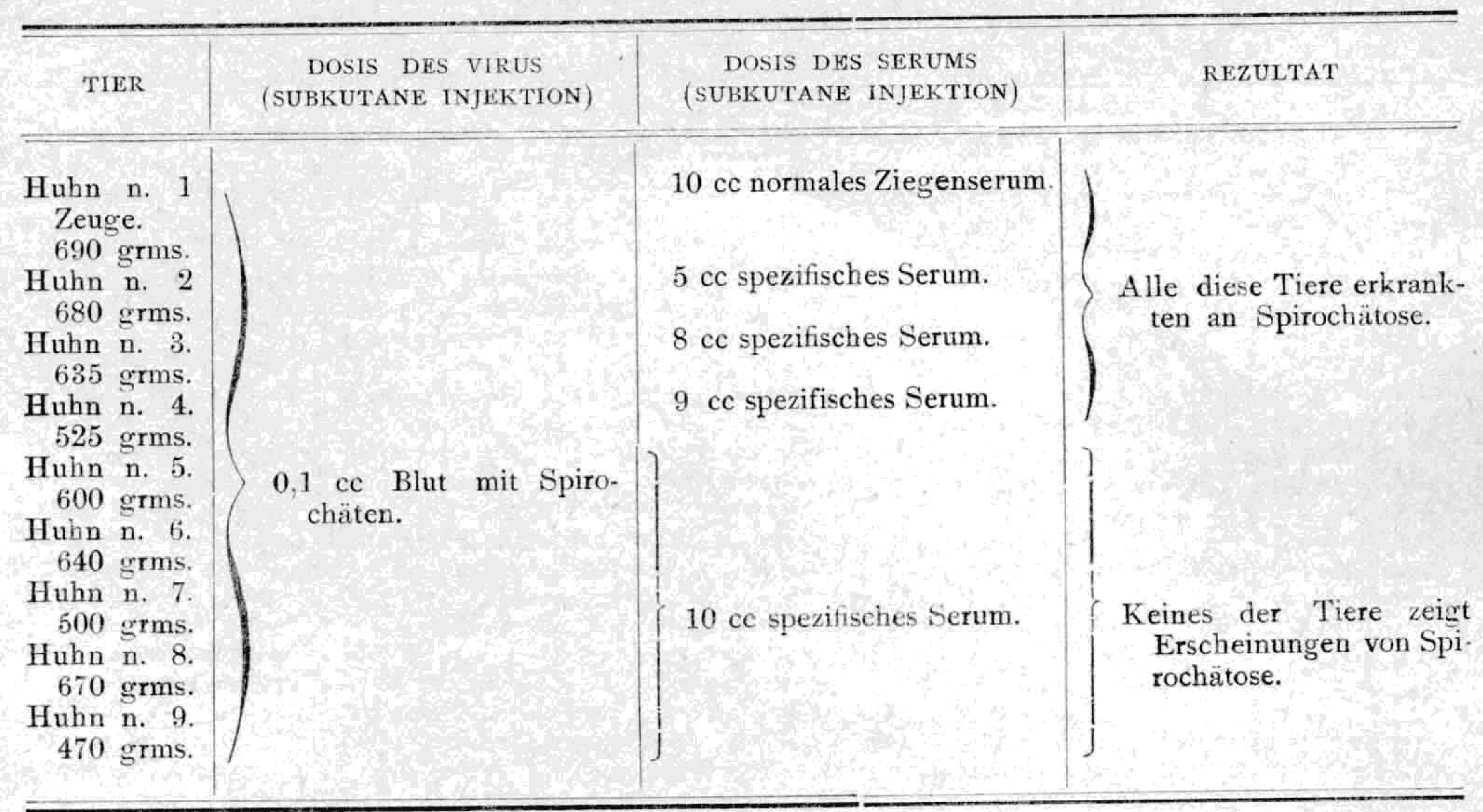


Série $L$

Ensaio do soro da cabra DS

(Antiespiroquetico nåo hemolitico)

Animais tratados 24 horas apóz a infeção

\begin{tabular}{|c|c|c|c|}
\hline ANIMAL & $\begin{array}{l}\text { QUANT. DE GERMENS } \\
\text { (INJEÇAO SUB-CUTANEA) }\end{array}$ & $\begin{array}{l}\text { QUANT. DE SORO } \\
\text { (INJEÇAO SUB-CUTANEA) }\end{array}$ & REZULTADO \\
\hline $\begin{array}{l}\text { Frango n. } 1 \\
\text { Testemunha } \\
750 \text { grms. } \\
\text { Frango n. } 2 \\
740 \text { grms. } \\
\text { Frango n. } 3 \\
670 \text { grms. } \\
\text { Frango n. } 4 \\
595 \text { grms. } \\
\text { Frango n. } 5 \\
660 \text { grms. } \\
\text { Frango n. } 6 \\
680 \text { grms. } \\
\text { Frango n. } 7 \\
700 \text { grms. } \\
\text { Frango n. } 8 \\
645 \text { grms. }\end{array}$ & $\begin{array}{l}0, \text { cc de sanive com espi- } \\
\text { roquetes. }\end{array}$ & $\begin{array}{l}10 \text { cc soro normal de cabra. } \\
5 \text { cc soro especifico. } \\
8 \mathrm{cc} \text { soro especifico. } \\
10 \mathrm{cc} \text { soro especifico. }\end{array}$ & $\begin{array}{l}\text { Todos estes animaes ad- } \\
\text { quiriram espiroquetoze. }\end{array}$ \\
\hline
\end{tabular}

Série $L$

Versuche mit Serum von Ziege DS

(Nicht bämolytisches Serum gegen Spirochätose)

24 Stunden nach der Infektion behandelte Tiere

\begin{tabular}{|c|c|c|c|}
\hline TIER & $\begin{array}{c}\text { DOSIS DES VIRUS } \\
\text { (SUBKUTANE INJEKTION) }\end{array}$ & $\begin{array}{c}\text { DOSIS DES SERUMS } \\
\text { (SUBKUTANE INJEKTION) }\end{array}$ & RESULTAT \\
\hline $\begin{array}{r}\text { Huhn n. } 1 \\
\text { Zeuge } \\
750 \text { grms. } \\
\text { Huhn n. } 2 \\
740 \text { grms. } \\
\text { Huhn n. } 3 \\
670 \text { grms. } \\
\text { Huhn n. } 4 \\
595 \text { grms. } \\
\text { Huhn n. } 5 \\
660 \text { grms. } \\
\text { Huhn n. } 6 \\
680 \text { grms. } \\
\text { Huhn n. } 7 \\
700 \text { grms. } \\
\text { Huhn n. } 8 \\
645 \text { grms. }\end{array}$ & $\begin{array}{l}\text { 0, cc Blut mit Spiro- } \\
\text { chäten. }\end{array}$ & $\begin{array}{l}10 \text { cc normales Ziegense- } \\
\text { rum. } \\
5 \text { cc spezifisches Serum. } \\
8 \text { cc spezifisches Serum. } \\
10 \text { cc spezifisches Serum. }\end{array}$ & $\begin{array}{l}\text { Alle diese Tiere erkrank- } \\
\text { ten an Spirochätose. } \\
\text { Keines der Tiere zeigt } \\
\text { Erscheinung von Spiro- } \\
\text { chätose. }\end{array}$ \\
\hline
\end{tabular}


Serie $M$

Ensaio do soro das cabras BS e DS

(Injeção intravenoza)

Animais tratados 6 horas apóz a infeção

\begin{tabular}{|c|c|c|c|}
\hline ANIMAL & $\begin{array}{l}\text { QUANT. DE GERMENS } \\
\text { (INJEÇAO SUB-CUTANEA) }\end{array}$ & $\begin{array}{c}\text { QUANT. DE SORO } \\
\text { (INJEÇAOO SUB-CUTANEA) }\end{array}$ & REZULTADO \\
\hline $\begin{array}{c}\text { Frango n. } 1 \\
\text { Testemunha } \\
600 \text { grms. } \\
\text { Frango n. } 2 \\
525 \text { grms. } \\
\text { Frango n. } 3 \\
610 \text { grms. } \\
\text { Frango n. } 4 \\
620 \text { grms. } \\
\text { Frango n. } 5 \\
500 \text { grms. } \\
\text { Frango n. } 6 \\
570 \text { grms. } \\
\text { Frango n. } 7 \\
630 \text { grms. } \\
\text { Frango n. } 8 \\
640 \text { grms. } \\
\text { Frango n. } 9 \\
555 \text { grms. }\end{array}$ & $\begin{array}{l}0,1 \text { cc de sangue com espi- } \\
\text { roquetes. }\end{array}$ & $\begin{array}{l}3 \text { cc soro especifico } \\
\text { cabra BS. } \\
3 \text { cc soro especifico } \\
\text { cabra BS. }\end{array}$ & $\begin{array}{l}\text { Este animal adquiriu es- } \\
\text { pirochaetose. } \\
\text { Morreu } 2 \text { horas apóz a } \\
\text { injeção. } \\
\text { Morreu } 40 \text { minutos apóz } \\
\text { a injecção. } \\
\text { Morreu } 5 \text { horas apóz a } \\
\text { injeção. } \\
\text { Morreu } 2 \text { horas apóz a } \\
\text { injeção. } \\
\text { Estes animais não se re- } \\
\text { sentiram absolutamente } \\
\text { da injeção intravenoza. } \\
\text { Nenhum delles adqui- } \\
\text { riu espiroquetoze. }\end{array}$ \\
\hline
\end{tabular}

Serie $M \quad$ Versuche mit Serum von Ziegen BS und DS

(Intravenöse Injektion)

\section{Stunden nach der Infektion behandelte Tiere}

\begin{tabular}{|c|c|c|c|}
\hline TIER & $\begin{array}{c}\text { DOSIS DES VIRUS } \\
\text { (SUBKUTANE INJECTION) }\end{array}$ & $\begin{array}{c}\text { DOSIS DES SERUMS } \\
\text { (SUBKUTANE } \\
\text { INJEKTION) }\end{array}$ & RESULTAT \\
\hline $\begin{array}{rc}\text { Huhn } & \text { n. } 1 \\
\text { Zeuge } & \\
600 & \text { grms. } \\
\text { Huhn } & \text { n. } 2 \\
525 & \text { grms. } \\
\text { Huhn } & \text { n. } 3 \\
610 & \text { grms. } \\
\text { Huhn } & \text { n. } 4 \\
620 & \text { grms. } \\
\text { Huhn } & \text { n. } 5 \\
500 & \text { grms. } \\
\text { Huhn } & \text { n. } 6 \\
570 & \text { grms. } \\
\text { Huhn } & \text { n. } 7 \\
630 & \text { grms. } \\
\text { Huhn } & \text { n. } 8 \\
640 & \text { grms. } \\
\text { Huhn } & \text { n. } 9 \\
555 & \text { grms. }\end{array}$ & $\begin{array}{l}0,1 \text { cc Blut mi Spiro- } \\
\text { chäten. }\end{array}$ & $\left\{\begin{array}{l}3 \mathrm{cc} \text { normales Ziegenserum } \\
3 \text { cc spezifisches Serum } \\
\text { Ziege BS. }\end{array}\right.$ & $\begin{array}{l}\text { Erkrankte an Sipirachä- } \\
\text { tose. } \\
+2 \text { Stunden nach der } \\
\text { Injektion. } \\
+40 \text { Minuten nach der } \\
\text { Injektion. } \\
+5 \text { Stunden nach der } \\
\text { Injektion. } \\
+2 \text { Stunden nach der } \\
\text { Injektion. } \\
\text { Die Tiere zeigten keine } \\
\text { Reaktion nach der } \\
\text { sub-kutanen Injektion } \\
\text { und keine derselben er- } \\
\text { kranktean Spirochätose. }\end{array}$ \\
\hline
\end{tabular}


Ensaio do soro das cabras BS e DS

(Injeção intravenoza)

Animais tratados 18 horas apóz a infeçãa

\begin{tabular}{|c|c|c|c|}
\hline ANIMAL & $\begin{array}{l}\text { QUANT. DE (IERMENS } \\
\text { (INJEÇĀO SUB-CUTANEA) }\end{array}$ & $\begin{array}{c}\text { QUANT. DE SORO } \\
\text { (INJEÇAO SUB-CUTANEA) }\end{array}$ & KEZUITADO \\
\hline $\begin{array}{l}\text { Frango n. } 1 \\
\text { Testemunha } \\
670 \text { grms. } \\
\text { Frango } \mathrm{n} .2 \\
630 \text { grms. } \\
\text { Frango n. } 3 \\
610 \text { grms. } \\
\text { Frango n. } 4 \\
690 \text { grms. } \\
\text { Frango } \mathrm{n.} 5 \\
700 \text { grms. } \\
\text { Frango } \mathrm{n} .6 \\
560 \text { grms. } \\
\text { Frango } \mathrm{n} .7 \\
645 \text { grms. } \\
\text { Frango } \mathrm{n} .8 \\
710 \text { grms. } \\
\text { Frango } \mathrm{n.} 9 \\
670 \text { grms. }\end{array}$ & $\begin{array}{l}0,1 \text { ec de sangue com espi- } \\
\text { roquetes. }\end{array}$ & $\begin{array}{l}5 \text { cc suro especificu } \\
\text { cabra DS. } \\
5 \text { cc soro especitico } \\
\text { cabra DS. }\end{array}$ & $\begin{array}{l}\text { Este animal adquiriu espiri- } \\
\text { loze. } \\
\text { Morreú } 35 \text { minutos apóz a } \\
\text { injeção. } \\
\text { Morreu } 20 \text { minutos apóz a } \\
\text { injeção. } \\
\text { Morreu } 50 \text { minutos apóz a } \\
\text { injeção. } \\
\text { Morreu } 15 \text { minutos apóz a } \\
\text { injeção. } \\
\text { Estes_anim aes não se re- } \\
\text { sentiram absolutamente } \\
\text { da injeção intravenoza. } \\
\text { Nenhum d'elles adqui- } \\
\text { riu espiroquetoze. }\end{array}$ \\
\hline
\end{tabular}

Serie $N \quad$ Versuche mit Serum von $Z$ iegen BS und DS

(Intravenöse Injektion)

18 Stunden nach der Infektion behandelte Tiere

\begin{tabular}{|c|c|c|c|}
\hline TIER & $\begin{array}{c}\text { DOSIS DES VIRUS } \\
\text { (SUBKUTANE' INJEKTION) }\end{array}$ & $\begin{array}{c}\text { DOSIS DES SERUMS } \\
\text { (SUBKUTANE INJEKTION) }\end{array}$ & RESULTA'T \\
\hline $\begin{array}{r}\text { Huhn n. } 1 \\
\text { Zeuge } 6 . \\
670 \text { grms. } \\
\text { Huhn n. } 2 \\
630 \text { grms. } \\
\text { Huhn n. } 3 \\
610 \text { grns. } \\
\text { Huhn } \text { n. } 4 \\
690 \text { grms. } \\
\text { Huhn n. } 5 \\
700 \text { grms. } \\
\text { Huhn n. } 6 \\
560 \text { grms. } \\
\text { Huhn } \text { n. } 7 \\
645 \text { grms. } \\
\text { Huhn n. } 8 \\
710 \text { grms, } \\
\text { Huhn } \\
670 \text { grms. } 9\end{array}$ & $\begin{array}{l}0,1 \text { cc Blut mit Spiro- } \\
\text { chäten. }\end{array}$ & $\begin{array}{l}5 \text { cc spezifisches Serum } \\
\text { Ziege BS. } \\
5 \text { cc sperifisches Serum } \\
\text { Ziege DS. }\end{array}$ & $\begin{array}{l}\text { Erkrankte an Spirochätose } \\
+35 \text { Minuten nach der } \\
\text { †njektion. } \\
\text { † Minuten nach der } \\
\text { Injektion. } \\
\text { † Minuten nach der } \\
\text { Injektion. } \\
\text { † Minuten nach der } \\
\text { Injektion. } \\
\text { Die Tiere zeig!en keine } \\
\text { Reaktion nach der sub- } \\
\text { kutanen Injektion und } \\
\text { keines derseiben er- } \\
\text { krankte an Spirochä- } \\
\text { tose }\end{array}$ \\
\hline
\end{tabular}


Série $O$ Verificações feitas com a vaccina contra a espiroquetose da gallinha

\section{Dose minima imunizante}

\begin{tabular}{|c|c|c|c|}
\hline $\begin{array}{l}\text { ANIMAL ( PESO OS- } \\
\text { CILANDO ENTRE } \\
600 \text { e } 800 \text { GRMS. }\end{array}$ & $\begin{array}{l}\text { QUANTIDADE DA VACCINA } \\
\text { (VIA SUB-CUTANEA) }\end{array}$ & $\begin{array}{l}\text { QUANTIDADE DE SANGUE INFE- } \\
\text { TANTE INOCULADO } 1 \text { MEZ } \\
\text { APÓS A VACCINAÇÃO. VIA } \\
\text { SUB-CUTANEA. }\end{array}$ & REZULTADO \\
\hline Frangos 1 a 4 & $0,01 \mathrm{cc}$ & & $\left\{\begin{array}{l}\text { Todos os frangos deste } \\
\text { grupo se apresentaram } \\
\text { infetados. }\end{array}\right.$ \\
\hline Frangos 5 a 8 & $0,05 \mathrm{cc}$ & & $\left\{\begin{array}{l}\text { Sómente o frango n. } 8 \\
\text { se infetou. }\end{array}\right.$ \\
\hline $\begin{array}{l}\text { Frangos } 9 \text { a } 12 \\
\text { Frangos } 13 \text { a } 16 \\
\text { Frangos } 17 \text { a } 20\end{array}$ & $\begin{array}{ll}0,1 & \mathrm{cc} \\
0,5 & \mathrm{cc} \\
1 & \mathrm{cc}\end{array}$ & $0,1 \mathrm{cc}$ & $\begin{array}{l}\text { Nenhum destes animaes } \\
\text { se infetou. }\end{array}$ \\
\hline $\begin{array}{r}\text { Frangos } 21 \text { a } 24 \\
\text { (Testemunhas) }\end{array}$ & $0 \quad \mathrm{cc}$ & & $\left\{\begin{array}{l}\text { Todos os frangos deste } \\
\text { grupo adquiriram a } \\
\text { espiroquetose. }\end{array}\right.$ \\
\hline
\end{tabular}

\section{Série $O \quad$ Versuche mit Vaccine gegen Huehner spirochaetose}

\section{Kleinste immunisierende Dose}

\begin{tabular}{|c|c|c|c|}
\hline $\begin{array}{l}\text { TIER } \\
\text { GEWICHT } 600 \\
800 \text { GRMS. }\end{array}$ & $\begin{array}{c}\text { DOSE DER VACCINE } \\
\text { (SUBKUTANE INIEKTION) }\end{array}$ & $\begin{array}{l}1 \text { MONAT NACH IMPFUNG INII- } \\
\text { ZIERTE DOSE VON VIRULEN- } \\
\text { TĖM BLUTE. }\end{array}$ & RESUITAT \\
\hline Hühner 1 a 4 & $0,01 \mathrm{cc}$ & & $\begin{array}{l}\text { Sämtliche Hühner er- } \\
\text { krankten an Spirochä- } \\
\text { tose. }\end{array}$ \\
\hline Hühner 5 a 8 & $0,05 \mathrm{cc}$ & & Nur n. 8 erkrankte. \\
\hline $\begin{array}{l}\text { Hühner } 9 \text { a } 12 \\
\text { Hühner } 13 \text { a } 16 \\
\text { Hühner } 17 \text { a } 20\end{array}$ & $\begin{array}{ll}0,1 & \mathrm{cc} \\
0,5 & \mathrm{cc} \\
1 & \mathrm{cc}\end{array}$ & $0,1 \mathrm{cc}$ & $\left\{\begin{array}{c}\text { Keines dieser Tiere } \\
\text { erkrankte. }\end{array}\right.$ \\
\hline $\begin{array}{l}\text { Hühner } 21 \text { a } 24 \\
\text { Zeugen }\end{array}$ & $0 \quad \mathrm{cc}$ & & $\begin{array}{l}\text { Sämmtliche Hühner } \\
\text { erkrankten an Spiro- } \\
\text { chätose. }\end{array}$ \\
\hline
\end{tabular}


Serie $P$

Verificaçóes da imunidade conferida pela vacina

ao cabo de 3 mezes

\begin{tabular}{|c|c|c|c|}
\hline $\begin{array}{c}\text { ANIMAL } \\
\text { PEZO ENTRE } 600 \\
\text { E } 800 \text { GRMS. }\end{array}$ & $\begin{array}{l}\text { QUANTIDADE DE VACINA } \\
\text { (VIA SUB-CUTANIA) }\end{array}$ & $\begin{array}{l}\text { QUANTIDADE DE SANGUE INFE- } \\
\text { TANTE INOCULADO } 3 \text { MEZES } \\
\text { APOZ A VACINAÇAO. } \\
\text { VIA SUB-CUTANEA }\end{array}$ & REZULTADO \\
\hline $\begin{array}{ll}\text { Frango } & 1 \\
\text { Frango } & 2 \\
\text { Frango } & 3 \\
\text { Frango } & 4 \\
\text { Frango } & 5 \\
\text { Frango } & 5 \\
\text { Frango } & 6 \\
\text { Frango } & 7 \\
\text { Frango } & 8 \\
\text { Frango } & 9 \\
\text { Frango } & 10 \\
\text { Frango } & 11 \\
\text { Frango } & 12 \\
\text { Frango } & 13 \\
\text { Testemunha } \\
\text { Frango } & 14 \\
\text { Testemunha }\end{array}$ & $\begin{array}{l}1 \mathrm{cc} \\
0 \mathrm{cc}\end{array}$ & $0,1 \mathrm{cc}$ & $\left\{\begin{array}{l}\text { Nenhum destes animais } \\
\text { se aprezentou infetado. } \\
\left\{\begin{array}{l}\text { Os frangos } 13 \text { e } 14 \text { ad- } \\
\text { quiriram esprioque- } \\
\text { tose. }\end{array}\right.\end{array}\right.$ \\
\hline
\end{tabular}

\section{Serie $P \quad$ Immunitätsversuche mit Vaccine nach 3 Monaten}

\begin{tabular}{|c|c|c|c|}
\hline $\begin{array}{l}\text { TIER } \\
\text { GEWICHT } 600-800 \\
\text { GRMS. }\end{array}$ & $\begin{array}{c}\text { DOSIS DER VACCINE } \\
\text { (SUBKUTANE EINSPRITZUNG) }\end{array}$ & $\begin{array}{l}\text { 3 MONATE NACH INPFUNG INJI- } \\
\text { ZEIRTE DOSE VON VIRULEN- } \\
\text { TEM BLUTE. }\end{array}$ & RESULTAT \\
\hline \begin{tabular}{lr} 
Huhn & 1 \\
Huhn & 2 \\
Huhn & 3 \\
Huhn & 4 \\
Huhn & 5 \\
Huhn & 6 \\
Huhn & 7 \\
Huhn & 8 \\
Huhn & 9 \\
Huhn & 10 \\
Huhn & 11 \\
Huhn & 12 \\
Huhn & 13 \\
Zeuge \\
Huhn & 14 \\
\multicolumn{2}{c}{ Zeuge }
\end{tabular} & $\begin{array}{l}1 \mathrm{cc} \\
\left\{\begin{array}{l}\mathrm{cc} \\
0 \mathrm{cc}\end{array}\right.\end{array}$ & $0,1 \mathrm{cc}$ & $\begin{array}{l}\text { Keines dieser Tiere } \\
\text { erkrankte. } \\
\text { Die Hühner } 13 \text { und } 14 \\
\text { erkrankten an Spiro- } \\
\text { chätose. }\end{array}$ \\
\hline
\end{tabular}


Serie $Q \quad$ Verificação da imunidade conferida pela vacina ao cabo de 6 mezes

\begin{tabular}{|c|c|c|c|}
\hline $\begin{array}{c}\text { ANIMAL } \\
\text { PESO ENTRE } 600 \\
\text { E } 800 \text { GRMS. }\end{array}$ & $\begin{array}{l}\text { QUANTIDADE DE VACINA } \\
\text { (VIA SUB-CUTANEA) }\end{array}$ & $\begin{array}{c}\text { QUANTIDADE DE SANGUE INFE- } \\
\text { TANTE INOCULADO } 6 \text { MKZES } \\
\text { AP'Z A VACINAÇAO VIA SUB- } \\
\text { CUTANEA }\end{array}$ & REZULTADO \\
\hline $\begin{array}{ll}\text { Frango } & 1 \\
\text { Frango } & 2 \\
\text { Frango } & 3 \\
\text { Frango } & 4 \\
\text { Frango } & 5 \\
\text { Frango } & 6 \\
\text { Frango } & 7 \\
\text { Frango } & 8 \\
\text { Frango } & 9 \\
\text { Frango } 10 \\
\text { Frango } & 11 \\
\text { Frango } & 12 \\
\text { Frango } & 13 \\
\text { Frango } & 14 \\
\text { Testemunha } \\
\text { Frango } 15 \\
\text { Testemunha } \\
\text { Frango } 16 \\
\text { Testemunha }\end{array}$ & $\begin{array}{l}1 \mathrm{cc} \\
0 \mathrm{cc}\end{array}$ & $0,1 \mathrm{cc}$ & $\begin{array}{l}\text { Nenhum destes ani- } \\
\text { mais se aprezentou } \\
\text { infetado. } \\
\text { Os frangos ns. } 14,15 \\
\text { e } 16 \text { adquiriram a } \\
\text { espiroquetoze. }\end{array}$ \\
\hline
\end{tabular}

Serie $Q \quad$ Immunitaetsversuche mit Vaccine nach 6 Monaten

\begin{tabular}{|c|c|c|c|}
\hline $\begin{array}{l}\text { TIER RG- } \\
\text { WICHT } 600-800 \\
\text { GRMS. }\end{array}$ & $\left(\begin{array}{c}\text { DOSIS DER VACCINE } \\
\text { (SUBKUTANE EINSPRITZUNG) }\end{array}\right.$ & $\begin{array}{l}6 \text { MONATR NACE IMPFUNG IN- } \\
\text { JIZIERTE DOSE VON VIRU- } \\
\text { LENTEM BLUTE. }\end{array}$ & RRSULT $\Delta T$ \\
\hline $\begin{array}{cc}\text { Huhn } & \text { I } \\
\text { Huhn } & 2 \\
\text { Huhn } & 3 \\
\text { Huhn } & 4 \\
\text { Huhn } & 5 \\
\text { Huhn } & 6 \\
\text { Huhn } & 7 \\
\text { Huhn } & 8 \\
\text { Huhn } & 9 \\
\text { Huhn } & 10 \\
\text { Huhn } & 11 \\
\text { Huhn } & 12 \\
\text { Huhn } & 13 \\
\text { Huhn } & 14 \\
\text { Zeuge } \\
\text { Hubn 15 } \\
\text { Zeuge } \\
\text { Huhn 16 } \\
\text { Zeuge }\end{array}$ & $\int^{1 c c}$ & $0,1 \mathrm{cc}$ & $\begin{array}{l}\text { Keines dieser Tiere } \\
\text { erkrankte. } \\
\text { Die Hühner ns. 14, } \\
15 \text { und } 16 \text { erkrank- } \\
\text { ten an Spirocbä- } \\
\text { tose. }\end{array}$ \\
\hline
\end{tabular}


Serie $R$

Verificação da imunidade conferida pela vacina ao cabo de ro mezes

\begin{tabular}{|c|c|c|c|}
\hline $\begin{array}{l}\text { ANIMAL } \\
\text { PEZO ENTRE } 600 \\
\text { E } 800 \text { GRMS. }\end{array}$ & $\begin{array}{l}\text { QUANTIDADE DE VACINA } \\
\text { (VIA SUB-CUTANEA) }\end{array}$ & $\begin{array}{l}\text { QUANTIDAE DE SANGUE IN- } \\
\text { FETANTE INOCULAD } 10 \mathrm{ME}- \\
\text { ZES DEPOIS DA VACINACQAO. } \\
\text { VIA SUB-CUTANEA }\end{array}$ & REZULTADO \\
\hline $\begin{array}{ll}\text { Frango } & 1 \\
\text { Frango } & 2 \\
\text { Frango } & 3 \\
\text { Frango } & 4 \\
\text { Frango } & 5 \\
\text { Frango } & 6 \\
\text { Frango } & 7 \\
\text { Frango } 8 \\
\text { Frango } 9 \\
\text { Testemunha } \\
\text { Frango 10 } \\
\text { Testemunha } \\
\text { Frango 11 } \\
\text { Testemunba }\end{array}$ & $\begin{array}{l}1 \mathrm{cc} \\
\quad \\
\quad 1 \\
0 \mathrm{cc}\end{array}$ & $0,1 \mathrm{cc}$ & $\begin{array}{l}\text { Nenhum destes ani- } \\
\text { mais se aprezentou } \\
\text { infetado. } \\
\text { Todos estes animais } \\
\text { adquiriram a espiro- } \\
\text { quetoze. }\end{array}$ \\
\hline
\end{tabular}

Serie $R$ Immunitaetsversuche mit Vaccine nach ro Monaten

\begin{tabular}{|c|c|c|c|}
\hline $\begin{array}{l}\text { TIER } \\
\text { GEWICHT } 600 \\
-800 \text { GRMS. }\end{array}$ & $\begin{array}{c}\text { DOSE DER VACCINE } \\
\text { (SUBKUTANE ETASPRITZUNA) }\end{array}$ & $\begin{array}{l}10 \text { MONATE NACH IMPFUNG } \\
\text { INJIZIERTE DOSE VON } \\
\text { VIRULHM BLUTE. }\end{array}$ & RESULTAT \\
\hline \begin{tabular}{ll} 
Huhn & 1 \\
Huhn & 2 \\
Huhn & 3 \\
Huhn & 4 \\
Huhn & 5 \\
Huan & 6 \\
Huhn & 7 \\
Huhn & 8 \\
Huhn & 9 \\
Zeuge \\
Huhn 10 \\
\multicolumn{2}{c}{ Zeuge } \\
Huhn 11 \\
\multicolumn{2}{c}{ Zeuge }
\end{tabular} & $0 \mathrm{cc}$ & $\mathrm{C}, 1 \mathrm{cc}$ & $\begin{array}{l}\text { Keines dieser Tiere } \\
\text { erkrankte. } \\
\text { Sämmtliche Tiere er-- } \\
\text { krankten an Spiro- } \\
\text { chätose. }\end{array}$ \\
\hline
\end{tabular}


Serie $\mathbf{S}$ Verificação da imunidade conferida pela vacina ao cabo de I3 mezes

\begin{tabular}{|c|c|c|c|}
\hline $\begin{array}{c}\text { ANIMAL } \\
\text { PEZO WNTRE } 600 \\
\text { E } 800 \text { GRMS. }\end{array}$ & $\begin{array}{l}\text { QUANTIDADE DE VACINA } \\
\text { (VIA SUB-CUTANEA) }\end{array}$ & $\begin{array}{l}\text { QUANTIDADH DE SANGUK IN- } \\
\text { FETANTE INOCULADO } 13 \text { ME- } \\
\text { ZES APOS A VACINACÃO } \\
\text { VIA SUB-CUTANEA }\end{array}$ & REZULTAIO \\
\hline $\begin{array}{ll}\text { Frango } & \mathbf{1} \\
\text { Frango } & \mathbf{2} \\
\text { Frango } & 3 \\
\text { Frango } & \mathbf{4} \\
\text { Frango } & 5 \\
\text { Frango } & 6 \\
\text { Frango } & 7 \\
\text { Frango } & 8 \\
\text { Frango } & 9 \\
\text { Frango } & 10 \\
\text { Frango } & 11 \\
\text { Frango } & 12 \\
\text { Frango } & 13 \\
\text { Frango } & 14 \\
\text { Frango } & 15 \\
\text { Testemunha } & \text { Frango } 16 \\
\text { Testemunha } \\
\text { Frango } 17 \\
\text { Testemunha }\end{array}$ & $\begin{array}{l}1 \mathrm{cc} \\
0 \mathrm{cc}\end{array}$ & 0,1 cc & \begin{tabular}{|l} 
Nenhum destes animais \\
se apresentou infetado. \\
Todos estes animais ad- \\
quiriram espiroquetoze
\end{tabular} \\
\hline
\end{tabular}

Serie $S \quad$ Immunitaetsversuche mit Vaccine nach 13 Monaten

\begin{tabular}{|c|c|c|c|}
\hline $\begin{array}{c}\text { TIER } \\
\text { GEWICHT } 600 \\
-800 \text { GRMS. }\end{array}$ & $\begin{array}{c}\text { DOSIS DER VACCINE } \\
\text { (SUB-KUTANE RINSPRITZUNG) }\end{array}$ & $\begin{array}{l}13 \text { MONATE NACH IMPFUNG } \\
\text { INJIZIKRTE DOZE VON VIRU- } \\
\text { LENTKM BLUTE }\end{array}$ & RRSULTAT \\
\hline \begin{tabular}{lr} 
Huhn & 1 \\
Huhn & 2 \\
Huhu & 3 \\
Huhn & 4 \\
Huhn & 5 \\
Huhn & 6 \\
Huhn & 7 \\
Huhn & 8 \\
Huhn & 9 \\
Huhn & 10 \\
Huhn & 11 \\
Huhn & 12 \\
Huhn & 13 \\
Huhn & 14 \\
Huhn & 15 \\
\multicolumn{2}{c}{ Zeuge } \\
Huhn & 16 \\
\multicolumn{2}{c}{ Zeuge } \\
Huhn & 17 \\
\multicolumn{2}{c}{ Zeuge }
\end{tabular} & $1 \mathrm{cc}$ & $\begin{cases}1 \\
0,1 \mathrm{cc}\end{cases}$ & $\begin{array}{l}\text { Keines dieser Tiere er- } \\
\text { krankte. } \\
\text { Sämmtlich Tiere èr- } \\
\text { kranken an Spirochı̄- } \\
\text { tose. }\end{array}$ \\
\hline
\end{tabular}


Serie $T$ Verificação da rezistencia dos animais vacinados

a quantidades diversas de sangue infetante

\begin{tabular}{|c|c|c|c|}
\hline $\begin{array}{c}\text { ANIMAL } \\
\text { PEZO ENTRE } 600 \\
\text { E } 800 \text { GRMS. }\end{array}$ & $\begin{array}{l}\text { QUANTIDADE DE VACINA } \\
\text { (VIA SUB-CUEANEA) }\end{array}$ & $\begin{array}{l}\text { QUANTIDADE DE SANGUE INFE- } \\
\text { TANTE INOCULADO } 1 \text { MEZ } \\
\text { APOZ A VACINAÇAO. }\end{array}$ & REZULTADO \\
\hline $\begin{array}{ll}\text { Frango } & 1 \\
\text { Frango } & 2 \\
\text { Frango } & 3 \\
\text { Frango } & 4 \\
\text { Frango } & 5 \\
\text { Frango } & 6 \\
\text { Frango } & 7 \\
\text { Frango } & 8 \\
\text { Frango } & 9 \\
\text { Testemunha } \\
\text { Frango } & 10 \\
\text { Testemunba }\end{array}$ & $\begin{array}{l}1 \mathrm{cc} \\
0 \mathrm{cc}\end{array}$ & 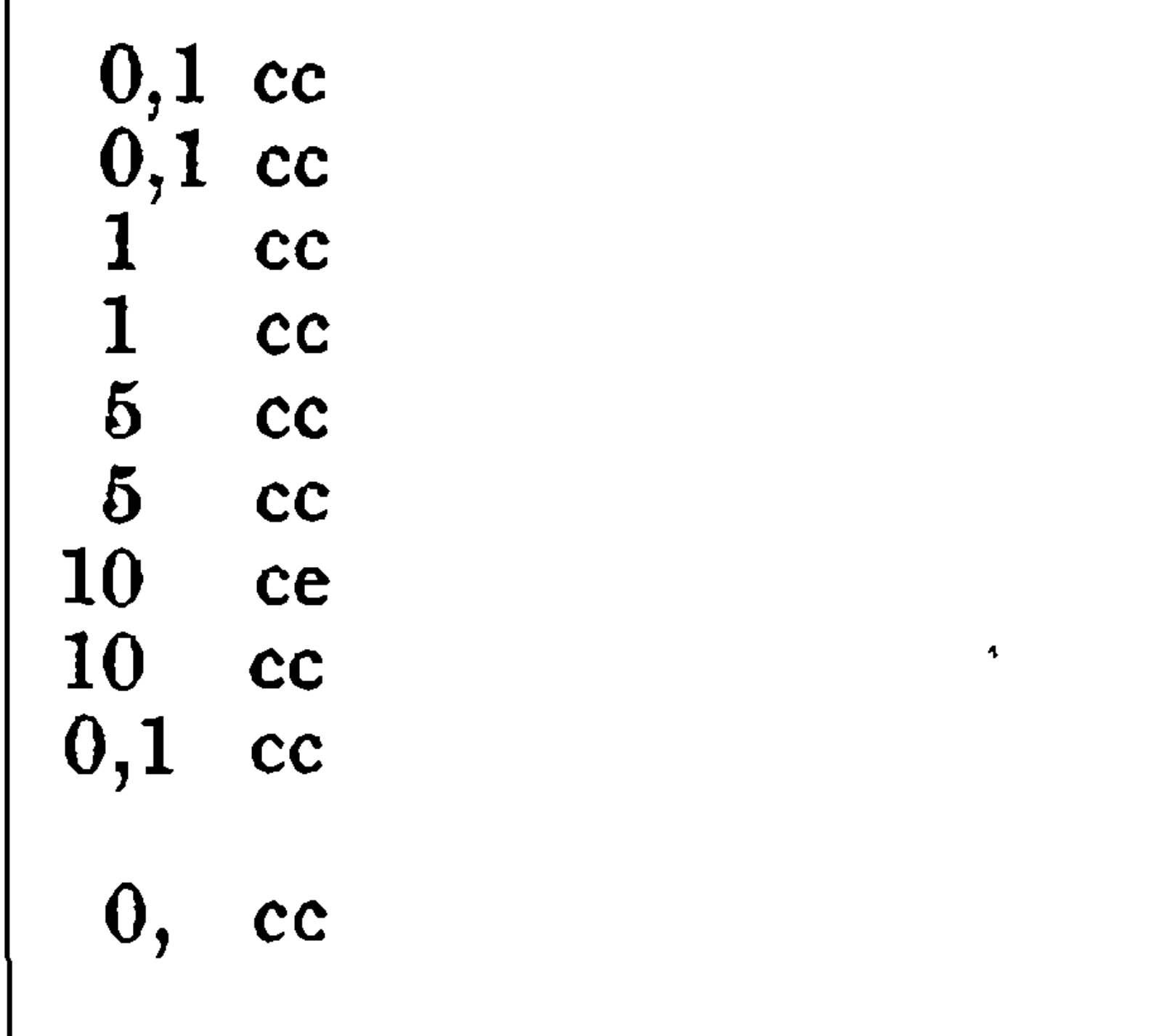 & $\begin{array}{l}\text { Nenhum destes animais } \\
\text { adquiriu a infeção. } \\
\text { Os frangos } 9 \text { e } 10 \text { ad- } \\
\text { quiriram a espiroque- } \\
\text { toze. }\end{array}$ \\
\hline
\end{tabular}

Serie $T \quad$ Resistenzversuche der mit verschiedenen Dosen virulenten Blutes vaccinierten Tiere

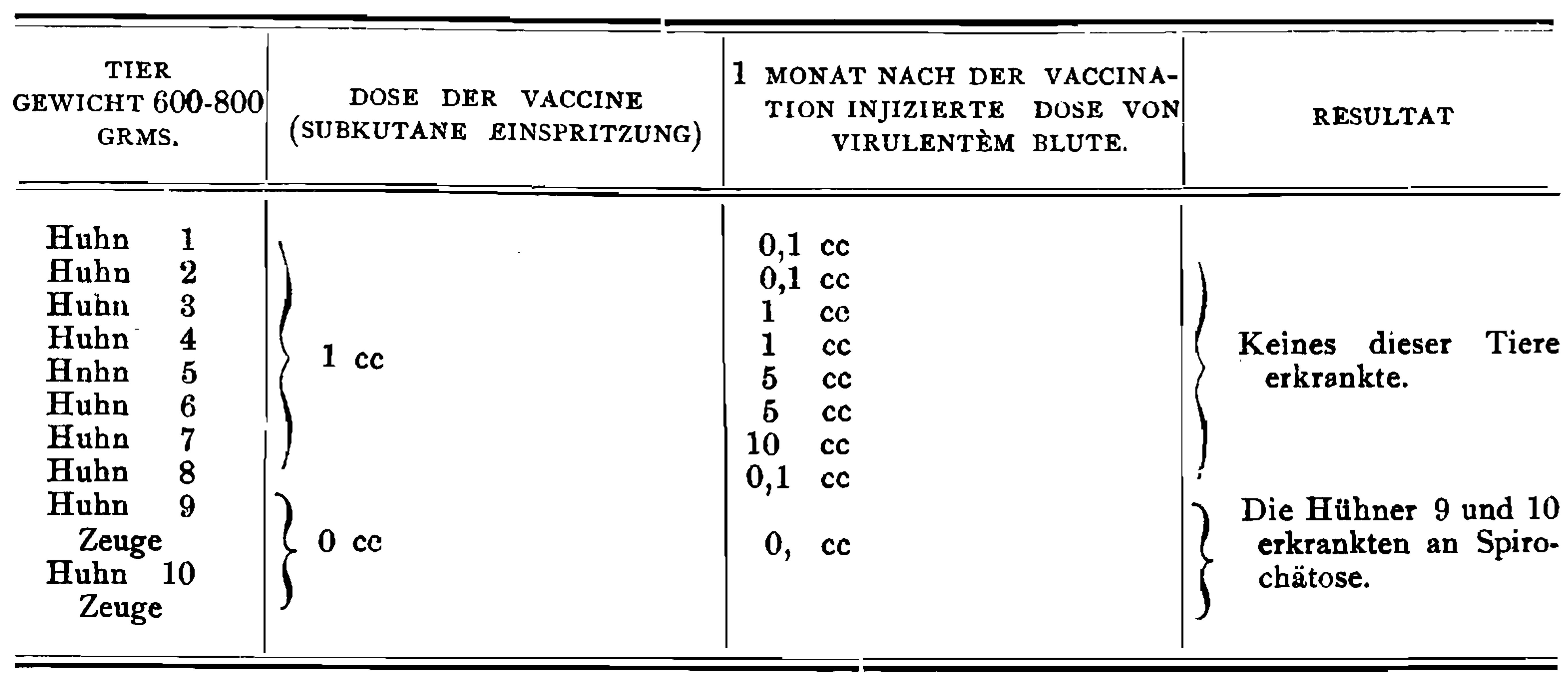


Serie $U$

Verificação da conservação do poder imunisante

da vacina feita I anno apóz o seu preparo

\begin{tabular}{|c|c|c|c|}
\hline $\begin{array}{c}\text { ANIMAL } \\
\text { PESO ENTRE } \\
600 \text { e } 800 \\
\text { GRMS. }\end{array}$ & $\begin{array}{c}\text { QUANT. DE VACOINA COM } 1 \\
\text { ANNO DE IDADE } \\
\text { (VIA SUB-CUTANEA) }\end{array}$ & $\begin{array}{c}\text { QUANT. DR SANGUR INFE- } \\
\text { TANTE INOCULADO } 1 \mathrm{MEZ} \\
\text { APÓZ. } \\
-\end{array}$ & REZULTADO \\
\hline $\begin{array}{ll}\text { Frango } & \text { n. } 1 \\
\text { Frango } & \text { n. } 2 \\
\text { Frango } & \text { n. } 3 \\
\text { Frango } & \text { n. } 4 \\
\text { Frango } & \text { n. } 5 \\
\text { Frango } & \text { n. } 6 \\
\text { Frango } & \text { n. } 7\end{array}$ & $1 \mathrm{cc}$ & $0,1 \mathrm{cc}$ & $\begin{array}{l}\text { Nenhum destes animaes } \\
\text { adquiriu a infecção. }\end{array}$ \\
\hline $\begin{array}{r}\text { Frango n. } 8 \\
\text { Testem unha } \\
\text { Frango n. } 9 \\
\text { Testemunhis }\end{array}$ & $\{0 \mathrm{cc}$ & & $\begin{array}{l}\text { Os frangos } 8 \text { e } 9 \text { ndqui- } \\
\text { riram a sspiriquetoze. }\end{array}$ \\
\hline
\end{tabular}

Serie $U$ Versuche ueber die Konservierung des Immunizierungsvermoegens der Vaccine' I Jahr nach ihrer Bereitung

\begin{tabular}{|c|c|c|c|}
\hline $\begin{array}{l}\text { TIER } \\
\text { GKWICHT } 600 \\
800 \text { GRMS. }\end{array}$ & $\begin{array}{l}\text { DOSE DRR VACCINE } 1 \text { JAHR } \\
\text { (SUBKUTANE WINSPRITZUNG.) }\end{array}$ & $\begin{array}{l}1 \text { MONAT NACH DHR VACCI- } \\
\text { NATION INJIZIERTE DOSH } \\
\text { VON VIRULENTEM BLUTE. }\end{array}$ & KESULTAT \\
\hline 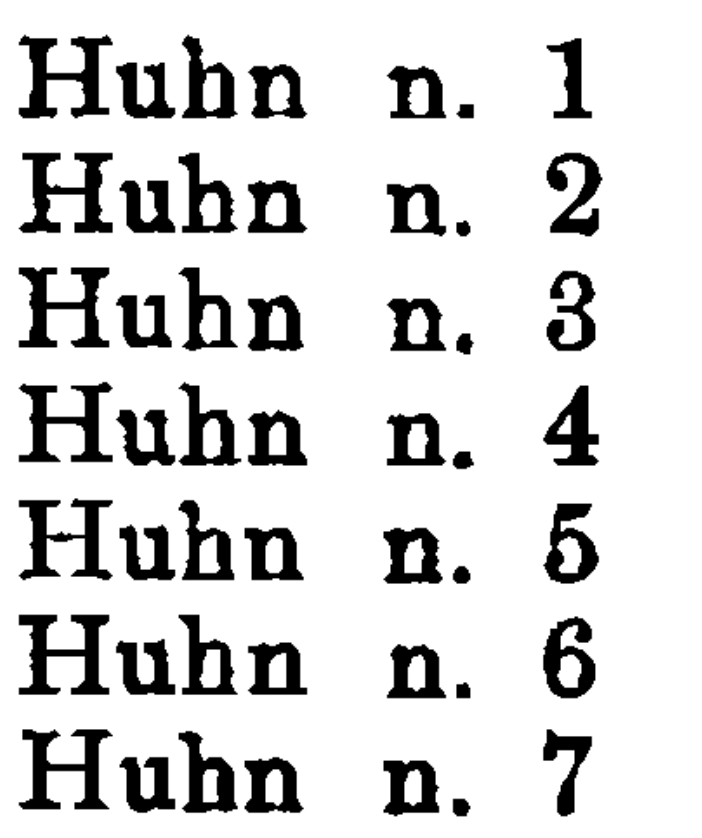 & $1 \mathrm{cc}$ & $0,1 \mathrm{cc}$ & $\begin{array}{l}\text { Keines dieser Tiere er- } \\
\text { krankte. }\end{array}$ \\
\hline $\begin{array}{l}\text { Huhn n. } 8 \\
\text { Zeuge } \\
\text { Hunh n. } 9 \\
\text { Zeuge }\end{array}$ & \}$_{0 \mathrm{cc}}$ & & $\begin{array}{l}\text { Die Hühner } 8 \text { und } 9 \text { er- } \\
\text { krankten an Spirochä- } \\
\text { tose. }\end{array}$ \\
\hline
\end{tabular}


Serie $V \quad$ Verificaçăo da rezistencia dos frangos vaccinados

a infeção pelos argas

\begin{tabular}{|c|c|c|c|}
\hline $\begin{array}{l}\text { ANIMAL } \\
\text { PEZO ENTRE } 600 \\
800 \text { GRMS. }\end{array}$ & $\begin{array}{c}\text { QUATIDADE DIE VACINA. } \\
\text { INJEGAO SUB-CUTANEA }\end{array}$ & $\begin{array}{c}\text { PRAZO ENTRE A VACINAGAO } \\
\text { E A PICADA DOS ARGAS } \\
\text { INFETADOS }\end{array}$ & REZULTADO \\
\hline $\begin{array}{ll}\text { Frango } & 1 \\
\text { Frango } & 2 \\
\text { Frango } & 3 \\
\text { Frango } & 4 \\
\text { Frango } & 5 \\
\text { Frango } & 6 \\
\text { Frango } 7 \\
\text { Frango } 8 \\
\text { Frango 9 } \\
\text { Testemunha } \\
\text { Frango 10 } \\
\text { Testemunha } \\
\text { Frango 11 } \\
\text { Testemunha } \\
\text { Frango 12 } \\
\text { Testemunha }\end{array}$ & $\begin{array}{l}1 \mathrm{cc} \\
0 \mathrm{cc}\end{array}$ & $\begin{array}{l}\{1 \text { mez. } \\
\left\{\begin{array}{l}3 \text { mezes. } \\
\left\{\begin{array}{l}\text { Picados pelos mesmos ar- } \\
\text { gas que os frangos } 1\end{array}\right. \\
\text { a } 4 \cdot\end{array}\right. \\
\left\{\begin{array}{c}\text { Picados pelos mesmos ar- } \\
\text { gas que os frangos } 5 \\
\text { a } 8\end{array}\right.\end{array}$ & $\begin{array}{l}\text { Nenhum destes frangos } \\
\text { adquiriu a espiroque- } \\
\text { toze. } \\
\text { Todos estes frangos ad- } \\
\text { quiriram a espiroque- } \\
\text { toze. }\end{array}$ \\
\hline
\end{tabular}

Seri $V$ Feststellung des Wiederstandes der geimpften Huehner gegen die Infektion durch den Biss der Argaszecken

\begin{tabular}{|c|c|c|c|}
\hline $\begin{array}{l}\text { TIRR } \\
\text { GWWICHT } 600 \\
-800 \text { GRMS. }\end{array}$ & $\begin{array}{l}\text { DOSE DER VACCINE } \\
\text { SUBKOTANE FINSPRITZUNG }\end{array}$ & $\begin{array}{l}\text { ZRITRAUM ZWISCHEN VAC- } \\
\text { CINATION UND ANSETZKN } \\
\text { DER ARASZFCKEN. }\end{array}$ & RESULTAT \\
\hline $\begin{array}{ll}\text { Huhn } & 1 \\
\text { Huhn } & 2 \\
\text { Huhn } & 8 \\
\text { Huhn } & 4 \\
\text { Huhn } & 5 \\
\text { Huhn } & 6 \\
\text { Huhn } & 7 \\
\text { Huhn } & 8 \\
\text { Huhn } & 9 \\
\text { Zeuge } \\
\text { Huhn } & 10 \\
\text { Zeuge } \\
\text { Huhn } & 11 \\
\text { Zeuge } \\
\text { Huhn } \\
\text { Zeuge }\end{array}$ & $1 \mathrm{cc}$ & 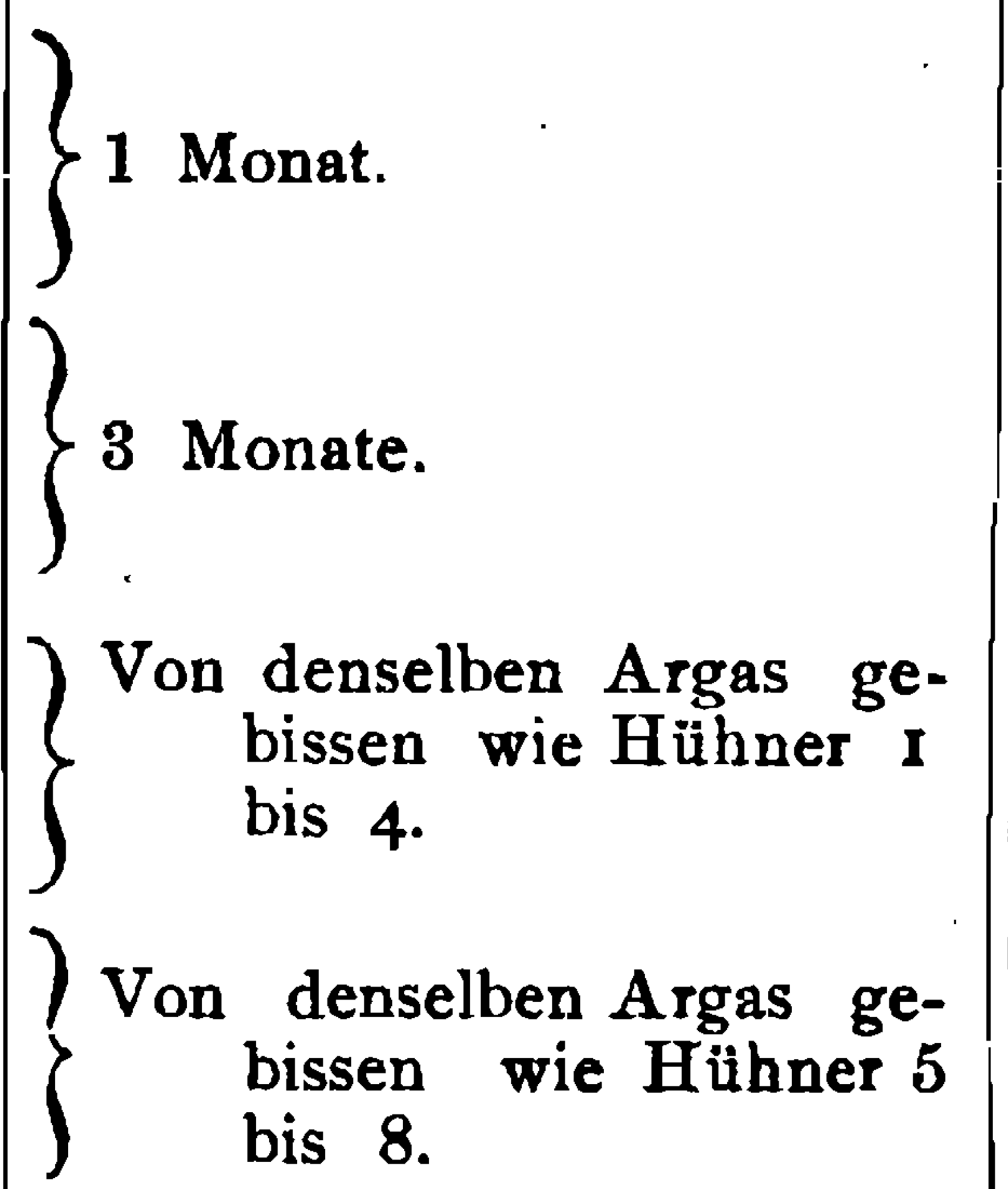 & $\begin{array}{l}\text { Keines dieser Tiere er- } \\
\text { krankte. } \\
\text { Alle diese Tiere er- } \\
\text { krankten an Spiro- } \\
\text { chätose. }\end{array}$ \\
\hline
\end{tabular}




\section{BIBLIOGRAFIA}

Aragão, H. B.

DUNGER, V.

LEVADITI

MARChOUX \& Simond

NEISSER \& LUBOWSKI

Pfetfer, R. \&

FRIEDBERGER,

REHNS, J

SACHS, $\mathrm{H}$.

Theiler, A.
1905 Ensaios de sorotherapia nas molestias produzidas por germens não cultivaveis.

Teze de doutouramento.

1900 Beitrag sur Immunitätslehre.

1904 Contribution à l'étude de la spirillose des poules. Ann. de l'Institut Pasteur. Tome 18. N. 3.

1906 Etudes sur la fièvre jaune.

Ann. de l'Institut Pasteur. Tome 20, N. I.

IgoI I,ässt sich durch Einspritzung der agglutinierten Typhusbacillen eine Agglutininproduction hervorrufen?

Centralbl. für Bakteriologie. Bd. 30, No. 13.

1902

Ueber das Wesen der Bakterienvirulenz nach Untersuchungen an Cholera-Vibrionen.

Berliner klinische Wochenschrift No. 50, 51.

Igor L'immunité active et les Toxines diphtériques surcompensées. Compt. Rend. Soc. Biol. p. I4I.

Igor Immunisirungsversuche mit Immunkörperbeladenen Erythrocyten.

Centralbl. für Bakteriologie. Bd. 3o, N. 13.

Igo5 Maladies des Troupeaux dans l'Afrique du Sud.

Bull. de l'Institut Pasteur. Tome III, No. 15. 